This is a peer-reviewed, accepted author manuscript of the following article: Doskaliyev, D., Poulopoulos, S. G., Yeshmuratov, A., Aldyngurova, F., Zorpas, A. A., \& Inglezakis, V. J. (2018). Effects of 2-chlorophenol and 2,4,6-trichlorophenol on an activated sludge sequencing batch reactor. Desalination and Water Treatment, 133, 283-291. https://doi.org/10.5004/dwt.2018.23065

\title{
Effects of 2-Chlorophenol and 2,4,6-Trichlorophenol on an Activated Sludge Sequencing Batch Reactor
}

\author{
D. Doskaliyeva , S.G. Poulopoulos ${ }^{\mathrm{a}}$, A. Yeshmuratov ${ }^{\mathrm{a}}$, F. Aldyngurova ${ }^{\mathrm{b}}$, A.A. Zorpas ${ }^{\mathrm{c}}$, V.J. \\ Inglezakis $^{\mathrm{a}^{*}}$ \\ ${ }^{a}$ School of Engineering, Chemical Engineering Department, Environmental Science \& \\ Technology Group (ESTg), Nazarbayev University, 53, Kabanbay Batyr Ave., Astana, 010000, \\ Kazakhstan,e-mails: daniyar.doskaliyev@nu.edu.kz,stavros.poulopoulos@nu.edu.kz, \\ abilmansur.yeshmuratov@nu.edu.kz,vasileios.inglezakis@nu.edu.kz \\ ${ }^{b}$ Astana Municipal Wastewater Treatment Plant, Korgalzhyn Highway, Astana, 020000, \\ Kazakhstan, e-mail: firyuza.ald@gmail.com \\ ${ }^{c}$ Cyprus Open University, Faculty of Pure and Applied Science Environmental Conservation and \\ Management, Lab of Chemical Engineering and Engineering Sustainability, Cyprus, \\ antonis.zorpas@ouc.ac.cy, antoniszorpas@yahoo.com \\ *Corresponding author: vasileios.inglezakis@nu.edu.kz
}

\begin{abstract}
In the present work, the effect of 2-chlorophenol and 2,4,6-trichlorophenol on the performance of a sequencing batch reactor operated with suspended municipal recycle activated sludge (RAS) in terms of total carbon and total nitrogen removal is presented. The total carbon removal achieved ranged in $80-100 \%$ and total nitrogen removal in 10-84\%. The results showed that chlorophenols did not inhibit either the activated sludge growth or the total carbon removal significantly. However, inhibition is observed in total nitrogen removal. 2-chlorophenol inhibited the ammonium oxidation (nitrification) while such an effect was not observed in the case of 2,4,6trichlorophenol indicating that the later inhibits the ammonification step. Furthermore, under the experimental conditions examined, complete removal of both chlorophenols was observed after few days of operation.
\end{abstract}

Keywords: 2-CP, 2,4,6-TCP, inhibition, sequencing batch reactor, activated sludge

\section{Introduction}

Chlorophenols represent the group of phenols in which chlorine atoms substitute hydrogen ions. There are many structural types of chlorophenols characterized by the number of chlorine atoms: monochlorophenols, dichlorophenols, trichlorophenols, tetrachlorophenols, and pentachlorophenol [1]. Chlorophenols have environmental and industrial origins. In environment, chlorophenols are produced through chlorination of mono and polyaromatic compounds in soil and water [2]. Industrial activities such as oil refining, textile, paper and pulp productions contribute to the presence of chlorophenols in effluents [3,4]. Uncontrolled discharge or poor treatment of wastewater containing chlorophenols poses serious hazards to the aquatic life and human health [2,5]. Thus, it is of primary importance to reduce chlorophenol concentrations in wastewaters below the levels set by legislation. One of the most popular and 
This is a peer-reviewed, accepted author manuscript of the following article: Doskaliyev, D., Poulopoulos, S. G., Yeshmuratov, A., Aldyngurova, F., Zorpas, A. A., \& Inglezakis, V. J. (2018). Effects of 2-chlorophenol and 2,4,6-trichlorophenol on an activated sludge sequencing batch reactor. Desalination and Water Treatment, 133, 283-291. https://doi.org/10.5004/dwt.2018.23065

efficient methods for treating chlorophenolic wastewater is the use of activated sludge Sequencing Batch Reactors (SBRs).

SBRs have been widely used for the treatment of wastewater containing various phenolic compounds. It has several advantages over Continuous Flow Reactors (CFRs) such as operating flexibility and control, minimal footprint, combination of equalization, primary clarification, biological treatment, secondary clarification in one reactor vessel, and potential cost savings by eliminating clarifiers [6,7]. The performance of SBRs in treating phenolic wastewater has been studied in Hybrid Growth (HG) and Suspended Growth (SG) modes. HG mode showed slightly higher phenol removal efficiency than SG; for phenol concentrations $25 \mathrm{mg} / \mathrm{L}, 50 \mathrm{mg} / \mathrm{L}, 75$ $\mathrm{mg} / \mathrm{L}$ and $100 \mathrm{mg} / \mathrm{L}, \mathrm{HG}$ SBR achieved removal efficiencies of $100 \%, 97 \%, 96 \%$, and 89\% compared to $99 \%, 95 \%, 86 \%$, and $79 \%$ by SG SBR [7]. When 2,4-DCP concentration was increased from 5 to 15 and $30 \mathrm{mg} / \mathrm{L}$, the removal efficiency dropped from $100 \%$ to about $91 \%$ and $41 \%$, respectively [8]. In SBRs, robust performance of activated sludge in chlorophenols removal is achieved by transforming it to aerobic granules. Aerobic granules are formed by aggregation of activated sludge into spherical flocs. Several factors such as the presence of hydrophobic bacteria, aeration rate, short settling time, and feed composition affect the aerobic granules formation. The performance of SBRs with aerobic granules for the treatment of 2chlorophenol in a wastewater showed 94\% COD removal [9]. Aerobic granules sustained increasing 2-chlorophenol concentrations from 20 to $140 \mathrm{mg} / \mathrm{L}$; variation of 2-CP did not affect the formation of aerobic granules. Aerobic granules were also reported to successfully remove $2,4,6-\mathrm{TCP}$ at concentrations up to $100 \mathrm{mg} / \mathrm{L}$ [10]. Above $93 \%$ of $2,4,6-\mathrm{TCP}$ removal was observed on the $42^{\text {nd }}$ day out of 50 after achieving full granulation in a sequencing batch airlift reactor (SBAR) [10,11]. For wastewater containing 2,4,6-TCP in the range of $10-360 \mathrm{mg} / \mathrm{L}$, removal efficiencies above $90 \%$ were reported. Activated sludge in the form of aerobic granules was more resistant to washout and could tolerate higher organic loading rates compared to its suspended form [12]. The performance of SBRs can also be affected when treating mixtures of different phenolic compounds. The biodegradation of a mixture of monosubstituted phenols such as P-nitrophenol (PNP) and PNP/o-cresol was fully achieved [13]. However, the biodegradation of P-nitrophenol (PNP) and o-cresol was inhibited due to the presence of o-chlorophenol (2-CP). Such an impact on biodegradation means that o-chlorophenol is highly toxic.

In biodegrading chlorophenols, bacteria can consume these toxic compounds as the sole carbon source for continuous growth [14]. However, especially at high concentrations, chlorophenols can inhibit the carbon oxidation. Addition of easily degradable carbon sources such as glucose or sodium acetate can facilitate faster bacteria growth. Increasing bacteria growth, in turn, can help to diminish the inhibiting impact of chlorophenols and to accelerate their degradation rates $[11,15]$.

In addition to the presence of co-substrates such as glucose or sodium acetate, the aeration during feed filling in SBRs can also affect pollutants' removal. The operation stages in an SBR reactor include FILL, REACT, SETTLE, and DRAW stages. The performance of two SBRs with aerated and anaerobic FILL modes that treated wastewater with phenol concentrations from 100 $\mathrm{mg} / \mathrm{L}$ to $1000 \mathrm{mg} / \mathrm{L}$ was compared, and it was shown that the different operation modes showed no meaningful variations, resulting in removal efficiencies above $99 \%$ at all concentrations [16]. SBR with aerated FILL showed faster biodegradation rate of phenol during REACT stage 
This is a peer-reviewed, accepted author manuscript of the following article: Doskaliyev, D., Poulopoulos, S. G., Yeshmuratov, A., Aldyngurova, F., Zorpas, A. A., \& Inglezakis, V. J. (2018). Effects of 2-chlorophenol and 2,4,6-trichlorophenol on an activated sludge sequencing batch reactor. Desalination and Water Treatment, 133, 283-291. https://doi.org/10.5004/dwt.2018.23065

compared to SBR with anaerobic FILL. This was explained by the fact that some of the phenols were already biodegraded during the aerated FILL stage. Thus, with aerated FILL stage, SBR needed shorter duration of REACT stage [17]. As a result, higher phenol removal could be accomplished. As phenol was degradable at aerobic conditions, accumulation of phenols during anaerobic FILL stage caused stress on bacteria and thus, inhibition. Significant inhibition by phenol was observed at $934 \mathrm{mg} / \mathrm{L}$. The nitrogen and phosphorus removal in an intermittently aerated (IASBR) and in a SBR was studied [18]. IASBR had 3 non-aeration and aeration cycles during REACT phase while SBR had one. SBR showed higher COD removal efficiency compared to IASBR. However, IASBR showed better performance than SBR regarding total nitrogen, ammonium, and phosphorus removal efficiency. Table 1 summarizes the response of activated sludge to the presence of phenol and various forms of chlorophenols in SBRs.

\section{[Table 1]}

From the Table 1, it can be concluded that chlorophenols have a stronger negative impact on nitrification compared to the organic carbon removal. Even complete removal of chlorophenols does not guarantee successful nitrification [20]. This demonstrates that nitrifying bacteria are very sensitive and weak to pollutants compared to heterotrophic bacteria.

The removal of chlorophenols and other volatile organic compounds (VOCs) from aqueous solutions can also occur due to aeration by stripping, a fact that has not been systematically studied in the related literature. Removal due to air stripping has been accounted for under the term "volatilization" in some studies [9,11,22]. Moreover, apart from air, ambient light in the process called photo-degradation has also been reported to contribute to the non-biological removal of chlorophenols. However, volatilization of 4-chlorophenol and 2,4,6-TCP has been generally found to be less than $5 \%$ and considered as negligible $[9,11,22]$. In these studies, volatilization and photo-degradation losses were evaluated using the same reactors and aeration but without sludge.

The aim of this study was to investigate the impact of 2-CP and 2,4,6-TCP on the performance of suspended activated sludge in an aerated SBR. The effect of 2-CP and 2,4,6-TCP was studied by measuring the bacteria growth (TSS), total organic carbon (TOC), total nitrogen (TN), nitrates production $\left(\mathrm{NO}_{3}{ }^{-}\right)$and phenols degradation. Moreover, the effect of aeration on the removal of 2CP, 2,4,6-TCP, TOC and TN was studied.

\section{Materials \& Methods}

\subsection{Sequencing Batch Reactors}

Two plexiglass Armfield W11 reactors were used. They had a cylindrical shape with inner diameter and height of $24 \mathrm{~cm}$ and $30 \mathrm{~cm}$, respectively, and working volume of $6.7 \mathrm{~L}$. In total 2.2 $\mathrm{L}$ of synthetic wastewater, $2.5 \mathrm{~L}$ of sludge, and $2 \mathrm{~L}$ of tap water were mixed in the reactors. Each reactor was equipped with a peristaltic pump that could be reconfigured to fill the reactor with the influent and to draw the effluent. At the bottom of each reactor, four equally- spaced in square pattern, internal aerators were located. The aeration rate was $3.0 \mathrm{~L} / \mathrm{min}$. An additional external aerator was added to help internal aerators to ensure suspension of the activated sludge during the operation. The hydraulic retention time (HRT) was 1.43 days and the total suspended 
This is a peer-reviewed, accepted author manuscript of the following article: Doskaliyev, D., Poulopoulos, S. G., Yeshmuratov, A., Aldyngurova, F., Zorpas, A. A., \& Inglezakis, V. J. (2018). Effects of 2-chlorophenol and 2,4,6-trichlorophenol on an activated sludge sequencing batch reactor. Desalination and Water Treatment, 133, 283-291. https://doi.org/10.5004/dwt.2018.23065

solids (TSS) $1.88 \pm 0.42 \mathrm{~g} / \mathrm{L}$. The inhibitor reactor contained chlorophenols while the baseline one not.

Non-acclimatized recycle activated sludge (RAS) was sampled from the local Municipal Wastewater Treatment Plant (Astana, Kazakhstan) with an estimated volatile suspended solids of $80 \% \mathrm{w} / \mathrm{w}$. After sampling, the sludge was aerated for 24 hours in order to reach endogenous respiration conditions. The initial reactor concentration of the wastewater is shown in Table 2.

\section{[Table 2]}

Experiments were conducted for two concentrations of 2-CP, $17 \pm 0.5$ and $51 \pm 1$ and one for 2,4,6TCP, 20 \pm 4 . Sodium acetate was added to baseline and inhibitor feed solutions to correct the TC concentration. The concentrations indicated are the averages over the duration of the experiments, and variations occur due to long operating times, which caused volatilization.

The average TOC, TN, and ammonium $\left(\mathrm{NH}_{4}{ }^{+}\right)$concentrations in the final feed solution with correction to reactor volume are $305 \pm 19,41.5 \pm 1.8$ and $11.7 \pm 0.7$, respectively. The $\mathrm{pH}$ of the feed solution was in the range of 7.51-7.98.

The Sequencing Batch Reactor (SBR) operation consisted of 4 stages: FILL (1h), REACT (20h), SETTLE (2h), and DRAW (1h). The first two stages were operated under aeration and the last two without aeration. One SBR operation cycle consisted of 24 hours. $2.2 \mathrm{~L}$ of feed solution was pumped into each reactor during the FILL stage. After REACT and SETTLE stages, the same $2.2 \mathrm{~L}$ of solution from the reactors were pumped out. The cycle repeated for 8 days to process 17.5 L of feed solution. To prevent feed solution quality degradation, two $8.75 \mathrm{~L}$ solutions were prepared separately, one after another, instead of bulk $17.5 \mathrm{~L}$ solution. The duration of experiments was between 190 and 194 hours.

The $\mathrm{pH}$ and Dissolved Oxygen (DO) were measured by means of Mettler Toledo FE20 and WTW inoLab Oxi 7310, respectively. The measurements were taken at the end of previous REACT and at the beginning of next REACT stages. Samples for TC, TN, Ion Chromotograph (IC), and High Performance Liquid Chromotography (HPLC) were taken from the $2.2 \mathrm{~L}$ effluent solutions of the reactors. The samples were filtered through $0.45 \mu \mathrm{m}$ syringe filters. $30 \% \mathrm{v} / \mathrm{v}$ sulfuric acid was used to preserve samples by reducing $\mathrm{pH}$ below 2 . TSS for each reactor was sampled twice and filtered through vacuum pump using $1.2 \mu \mathrm{m} \mathrm{GF} / \mathrm{F}$ glass microfiber filters.

\subsection{Air stripping experiments}

The air stripping experiments aimed at studying the effect of aeration on the removal of volatile compounds found in the synthetic wastewater. The wastewater composition was the same as in the rest of the experiments (Table 2). The same operating volumes were used in both reactors. The aeration modes used are shown in Table 3.

\section{[Table 3]}




\subsection{Analytical methods}

Ions such as ammonium and nitrate were analyzed using 930 Compact IC Flex (Metrohm). 2-CP and 2,4,6-TCP from the Inhibitor reactor influents and effluents were analyzed by Agilent 1290 UPHPLC Infinity II. Multi N/C 3100 by Analytik Jena AG was used to measure TC and TN. For microbiological analyses, samples of activated sludge were seeded in disposable plastic Pasteur dishes filled with standard agar feeding media using microbiological loop in aseptic conditions of laminate hood ( 2 class), and cultivated in incubator for 24 hours at $37^{\circ} \mathrm{C}$. After incubation, dished were examined under optical microscope.

\section{Results \& Discussion}

\subsection{Air stripping}

The results of air stripping experiments are shown in Figure 1. In the absence of sludge, internal and external aerators contributed to significant TC removal of $43.9 \%$ at $21 \mathrm{~h}$ operation. The addition of sludge resulted in a considerably higher removal of $85.1 \% \mathrm{TC}$. Also, internal and external aerations accounted for $29.4 \%$ and $10.5 \%$ removal of 2-CP and 2,4,6-TCP, respectively. These results showed that chlorophenols were relatively resistant to stripping, and present in the solution in considerable amounts throughout the experiment. As it is evident from Figure 1, in the absence of activated sludge, there was negligible carbon removal from the solution up to 8 hours of operation. With the addition of activated sludge, the carbon removal reached more than $50 \%$ during the same period. Although it was not possible to experimentally estimate the contribution of stripping on carbon removal in the presence of activated sludge, it was clear that, at least until 8 hours of operation, the effect of aeration was negligible. Thus, it can be concluded that the overall contribution of air stripping to carbon removal was much less than the $43.9 \%$ observed in the absence of activated sludge.

\section{[Figure 1]}

The lowest possible contribution from aeration could be achieved by using only internal aeration. Maximum internal aeration at $3.0 \mathrm{~L} / \mathrm{min}$ resulted in $34.9 \% \mathrm{TC}$ removal, and internal aeration at the half rate of $1.5 \mathrm{~L} / \mathrm{min}$ resulted in $28.6 \% \mathrm{TC}$ removal. Thus, even with mild aeration the contribution of stripping to the TC removal cannot be neglected, at least for lengthy experiments.

\section{2. pH and Dissolved Oxygen}

$\mathrm{pH}$ and DO are important operational parameters that affect bacteria activity. In Figures 2, 3, and 4, $\mathrm{pH}$ data for E1, E2, and E3 experiments are presented, respectively. At the beginning of the REACT stage, $10 \% \mathrm{v} / \mathrm{v} \mathrm{HCl}$ was added dropwise in order to set the initial $\mathrm{pH}$ at 7-7.5. As it is evident, $\mathrm{pH}$ increased during the REACT phase up to 8-8.5. The optimum $\mathrm{pH}$ value for biodegradation was between 6.5 and 8.5 [23]. Also, for nitrification, the suitable $\mathrm{pH}$ range was 7.5-8.5. Serious inhibition of nitrification took place at $\mathrm{pH}$ below 6 [24,25]. Thus, the observed 
$\mathrm{pH}$ range in E1, E2, and E3 experiments were within the limits for proper biodegradation and nitrification processes.

\section{[Figure 2]}

\section{[Figure 3]}

\section{[Figure 4]}

The DO profile for E1, E2, and E3 had the same trend, which was similar to $\mathrm{pH}$ ones, as shown in Figures 5, 6, and 7. DO was low at the beginning of REACT stage and increased by the end of the same stage. Oxygen consumption starts during the aerated FILL stage and low DO was associated with ongoing biodegradation and nitrification. By the end of the REACT stage, the decrease in oxygen consumption resulted in DO rise. DO for E1, E2, and E3 varied between about 0.8 and $7.5 \mathrm{mg} \mathrm{O}_{2} / \mathrm{L}$. The favorable $\mathrm{DO}$ values for aerobic bacteria activity was between 0.5 and $2.0 \mathrm{mg} \mathrm{O}_{2} / \mathrm{L}$ [23]. Observed DO values in E1, E2, and E3 were sufficiently high to provide the bacteria with adequate oxygen levels.

\section{[Figure 5]}

\section{[Figure 6]}

\section{[Figure 7]}

\subsection{Total Suspended Solids (TSS)}

2-CP and 2,4,6-TCP, being toxic, can inhibit the bacteria growth. Nevertheless, with some fluctuations, bacteria in all experimental runs showed a progressive growth trend throughout experiments, as shown in Figures 8 and 9. Thus, chlorophenols did not inhibit the bacteria growth at the concentrations used. Probably, this happened due to the availability of easily biodegradable organic compounds in the synthetic wastewater.

\section{[Figure 8]}

\section{[Figure 9]}

\subsection{TC removal results}

TC removal per TSS (or specific substrate utilization rate) was used to evaluate the activity of bacteria. Figures 10 and 11 present TC removals per TSS for E1, E2, and E3 baseline and inhibitor reactors. All reactors, with some fluctuations, showed decreasing specific substrate utilization values. The decrease of the specific substrate utilization rate indicated that the bacteria activity decreased also with time, and the trend was the same in all reactors. However, 2-CP at high concentration showed systematically lower values, which was an indication of carbon oxidation inhibition. 


\section{[Figure 10]}

\section{[Figure 11]}

As expected, the TC removal was high and almost constant, as shown in Figures 12 and 13. Evidently, the decrease of the substrate utilization rate was compensated by the increase of bacteria population in the reactors. The TC removal results showed no inhibition. According to literature, phenols exhibit different toxicity depending on several factors such as polarity, hydrophobicity, solubility and volatility and the toxicity towards carbon oxidation was found to follow the order 2-chlorophenol $>$ nitrophenol $>$ phenol $>$ resorcinol [27]. In particular, 2chlorophenol inhibited carbon oxidation by almost $100 \%$, but the concentration used in this study was $200 \mathrm{mg} / \mathrm{L}$ or higher.

\section{[Figure 12]}

\section{[Figure 13]}

\subsection{TN removal results}

Similarly to specific TC removal, TN removal per TSS in E1, E2, and E3 also exhibited decreasing trends, as shown in Figures 14 and 15. However, inhibitor reactors E1 and E2 had much lower removal trends compared to specific TC removals in the same experiments. TN removals per TSS in E1 and E2 approached zero values by the end of experiments. This was a strong indication of activity reduction of the nitrogen removing bacteria in 2-CP experiments, which was more potent in the higher 2-CP concentration. However, no clear conclusion can be drawn as the specific TN removal decreased in the baseline reactors as well. The trends were different in the case of 2,4,6-TCP, where the differences between the baseline and inhibitor reactors were progressively smaller than for 2-CP for longer times.

\section{[Figure 14]}

\section{[Figure 15]}

TN removal correlated well with specific TN removal, as shown in Figures 16 and 17 for E1, E2, and E3. TN removal for E1 inhibitor reactor did not exceed $20 \%$, which was low compared to TC removal achieved above $80 \%$. Similarly, for E2 inhibitor reactor, low TN removal per TSS resulted in a TN removal not exceeding 50\%. In contrast to it, the TC removal for the E2 Inhibitor reactor was above $80 \%$. Very low overall TN removals in inhibitor E1 and E2 reactors signal inhibition of the activity of nitrogen removing bacteria. TN removal in E3 Inhibitor reactor showed a similar to TN removal per TSS trend, generally stable, with a spike at about 150 hours. The relatively high $\mathrm{TN}$ removal can be explained by the combined effect of volatization during the REACT step and denitrification during the SETTLE and DRAW steps which last $3 \mathrm{~h}$ in total under absence of aeration.

\section{[Figure 16]}




\section{[Figure 17]}

\subsection{Ammonium consumption and nitrates production (nitrification)}

While TN data showed inhibitory effects of both chlorophenols, the cause seems to be different for each of them. Ammonium measurements showed significant inhibition of ammonia oxidation in the case of 2-CP (Figure 18). As it is clear, compared to inhibitor reactors, E1 and E2 baseline reactors demonstrated $100 \%$ ammonium removal. Studies have shown that phenols inhibit all bioprocesses but not to the same degree. For instance, autotrophic biomass (nitrification) was found to be more sensitive to phenol and nitrophenol than the aerobic heterotrophic biomass (carbon oxidation) in the concentrations range of $10-50 \mathrm{mg} / \mathrm{L}[28]$.

\section{[Figure 18]}

In contrast, at the presence of 2,4,6-TCP, ammonium oxidation was almost complete, as shown in Figure 19. Thus, the TN inhibition is due to ammonification problems. These results indicate that 2-CP was more toxic to nitrifying bacteria than 2,4,6-TCP. It was not clear whether the inhibition was temporary or permanent; research has shown that after stopping 2,4dichlorophenol feeding, nitrification was gradually recovered [8].

\section{[Figure 19]}

Figure 20 presents the nitrate production in the reactors. Close to zero nitrate production in E1 and E2 inhibitor reactors and increasing nitrate production in E1 and E2 Baseline reactors confirmed the observations on ammonium consumption, and it was clear that nitrification was inhibited by 2-CP. In contrast, nitrate production in the case of 2,4,6-TCP seemed to not be affected (Figure 21).

\section{[Figure 20]}

In all reactors, an initial decrease and then gradual increase of nitrates concentration was observed. However, the high concentration of nitrates at the beginning of the experiment was due to the residual nitrates contained in the activated sludge, which dropped due to the anaerobic conditions during the settling stage of the SBR. Then, the nitrates concentration gradually increased due to the acclimatization of the nitrifying bacteria and in the case of 2,4,6-TCP the degradation of the compound. The exception was the 2-CP reactors where nitrification seemed to be impaired.

\section{[Figure 21]}

The results of the microbiological analysis of activated sludge after $8 \mathrm{~d}$ contact with feed containing 2-CP is shown in Figure 22. The results showed that bacterial concentration was very high in all samples. As it is evident, the activated sludge, which was in contact with 2-CP feed, showed mono-cultured (homogeneous, presumably a single type of bacteria) colonies with 
This is a peer-reviewed, accepted author manuscript of the following article: Doskaliyev, D., Poulopoulos, S. G., Yeshmuratov, A., Aldyngurova, F., Zorpas, A. A., \& Inglezakis, V. J. (2018). Effects of 2-chlorophenol and 2,4,6-trichlorophenol on an activated sludge sequencing batch reactor. Desalination and Water Treatment, 133, 283-291. https://doi.org/10.5004/dwt.2018.23065

higher density of bacteria seeding compared to the activated sludge, which was in contact with feed without phenols. In the later, at least three bacteria varieties (one of them opalescent) were determined, including one colony of fungi (presumably from Candida genus), all marked with cycles in Figure 22. Although qualitative, it is a clear evidence of disappearance of some microbe types due to the toxic effect of 2-CP. The activated sludge showed no such characteristics when in contact with 2,4,6-TCP.

[Figure 22]

\subsection{Chlorophenols Removal}

Activated sludge in SBR demonstrated complete removal of 2-CP and 2,4,6-TCP, as can be seen in Figure 23. The removal trend in all reactors was the same. The sharp decrease could be attributed to the sludge acclimation to chlorophenols. As reaction went on, TSS was risen, and removal rates of 2-CP and 2,4,6-TCP also increased, achieving complete removal by the end of the experiment. The removal of chlorophenols depends on their initial concentrations as well as on the treatment duration [28]. Thus, depending on chlorophenol's initial concentration, SBRs may need an extended operation period to achieve full removal. The complete removal of phenols showed that the carbon oxidation processes and thus, the activity of the heterotrophic bacteria were not affected by these toxic compounds.

[Figure 23]

\section{Conclusions}

The results showed that the presence of chlorophenols is not significantly affect carbon oxidation. Inhibition was observed in total nitrogen removal and while in the case of 2-CP the cause is poor nitrification in the case of 2,4,6-TCP is poor ammonification. The higher the 2-CP concentration, the more evident the inhibition effect was. Both chlorophenols showed no inhibition towards bacteria growth, although there was some evidence of decreased activity, which however was not limited to inhibitor reactors alone. Finally, both chlorophenols were completely removed after few days of operation, which showed that bacteria were gradually acclimatized. Nevertheless, in the case of 2-CP, the nitrification inhibition did not show any decreasing trend, indicating thus that the damage to nitrifying bacteria was permanent.

\section{References}

[1] U.S. Department of Health and Human Services, Agency for Toxic Substances and Disease Registry, Public Health Service, Toxicological Profile for Chlorophenols, 1999.

[2] J.Michałowicz and W. Duda, Phenols - Sources and toxicity, Polish Journal of Environmental Studies, 16 (2006) 347-362.

[3] N.Christiansen, H.V. Hendriksen, K.T. Järvinen, and B.K. Ahring, Degradation of chlorinated aromatic compounds in UASB reactors, Water Science Technology, 31 (1995) 249-259.

[4] A. Vallecillo, P.A. Garcia-Encina, and M. Pena, Anaerobic biodegradability and toxicity of chlorophenols, Water Science Technology, 40 (1999) 161-168. 
This is a peer-reviewed, accepted author manuscript of the following article: Doskaliyev, D., Poulopoulos, S. G., Yeshmuratov, A., Aldyngurova, F., Zorpas, A. A., \& Inglezakis, V. J. (2018). Effects of 2-chlorophenol and 2,4,6-trichlorophenol on an activated sludge sequencing batch reactor. Desalination and Water Treatment, 133, 283-291. https://doi.org/10.5004/dwt.2018.23065

[5] World Health Organization (WHO), Chlorophenols in Drinking Water. Background Document for Development WHO Guidelines for Drinking Water Quality, Geneva, Switzerland, 1996.

[6] EPA (Environmental Protection Agency, US), Wastewater Technology Fact Sheet. Sequencing Batch Reactors, 1-9, 2009.

[7] N.A. Yusoff, S.A. Ong, L.N. Ho, Y.S. Wong, W.F Khalik, and S.L. Lee, Evaluation of biodegradation process: Comparative study between suspended and hybrid microorganism growth system in sequencing batch reactor (SBR) for removal of phenol, Biochemical Engineering Journal, 115 (2016) 1-28.

[8] J-W. Lim, S-L. Ng, S-M. Khor, and C-E. Seng, Inhibitory effect of 2,4 - dichlorophenol on nitrogen removal in a sequencing batch reactor, Korean Journal of Chemical Engineering, 29 (2012) 886-890.

[9] M. Zain Khan, P.K. Mondal, and S. Sabir, Bioremediation of 2-chlorophenol containing wastewater by aerobic granules-kinetics and toxicity, Journal of Hazardous Materials, 190 (2011) 222-228.

[10] M-S. Miao, Y-J. Zhang, L. Shu, J. Zhang, Q. Kong, and N. Li, Development and characterization of the 2,4,6 - trichlorophenol (2,4,6 - TCP) aerobic degrading granules in sequencing batch airlift reactor, International Biodeterioration \& Biodegradation, 95 (2014) 61-66.

[11] M. Zain Khan, P.J. Mondal, S. Sabir, and V.Tare, Degradation pathway, toxicity, and kinetics of 2,4,6 - TCP with different co-substrate by aerobic granules in SBR, Bioresource Technology, 102 (2011) 7016-7021.

[12] Q. Kong, J. Zhang, H.H. Ngo, S. Ni, S. Fu, N. Guo and L. Tian, Nitrous oxide emission in an aerobic granulation sequencing batch airlift reactor at ambient temperatures, International Biodeterioration \& Biodegradation, 85 (2013) 533-538.

[13] I. Fernández , M.E. Suárez-Ojeda, J. Pérez and J. Carrera, Aerobic biodegradation of a mixture of monosubstituted phenols in a sequencing batch reactor, Journal of Hazardous Materials, 260 (2013) 563-568.

[14] H.J. Knackmuss, Basic knowledge and perspectives of bioelimination of xenobiotic compounds, Journal of Biotechnology, 85 (1996) 533-538.

[15] A.K. Haritash and C.P. Kaushik, Biodegradation aspects of polycyclic aromatic hydrocarbons (PAHs): a review, Journal of Hazardous Materials, 169 (2009) 1-15.

[16] C.H. Chan and P.E. Lim, Evaluation of sequencing batch reactor performance with aerated and unaerated FILL periods in treating phenol-containing wastewater, Bioresource Technology, 98 (2007) 1333-1338.

[17] H.Q. Yu and G.W. Gu, Treatment of Phenolic Wastewater by Sequencing Batch Reactors with Aerated and Unaerated Fills, 16 (1996) 561-566.

[18] M. Pan, T. Chen, Z. Hu, and X. Zhan, Assessment of nitrogen and phosphorus removal in an intermittently aerated sequencing batch reactor (IASBR) and a sequencing batch reactor (SBR), Water Science and Technology, 68 (2013) 400-405.

[19] F.Kargi, A. Uygur, and H.S. Baskaya, para-Chlorophenol inhibition on COD, nitrogen, and phosphate removal from synthetic wastewater in a sequencing batch reactor, Bioresource Technology, 96 (2005) 1696-1702.

[20] Z.Hu, R.A.Ferraina, J.F.Ericson, A.A.MacKay, and B.F.Smets, Biomass characteristics in three sequencing batch reactors treating wastewater containing synthetic organic chemicals, Water Research, 39 (2005) 710-720. 
[21] A. Uygur and F. Kargi, Phenol inhibition of biological nutrient removal in a four-step Sequencing Batch Reactor, Process Biochemistry, 39 (2003) 2123-2128.

[22] A. Carucci, S. Milia, G. Cappai, and A. Muntoni, A direct comparison amongst different technologies (aerobic granular sludge, SBR and MBR) for the treatment of wastewater contaminated by 4-chlorophenol, Journal of Hazardous Materials, 177 (2010) 1119-1125.

[23] N.F. Gray, Biology of wastewater treatment, Imperial College Press, London, 2004.

[24] G. Tchobanoglous, F.L. Burton, and H.D. Stensel, Wastewater engineering: treatment and reuse, Metcalf\&Eddy, New York, 1991. [25] M.R.Templeton and D. Butler, Introduction to Wastewater Treatment, Ventus Publishing ApS, 2011.

[26] Z. Duan, Microbial degradation of phenol by activated sludge in a batch reactor, Environment Protection Engineering, 37 (2011) 53-63.

[27] V. Inglezakis, A. Kudarova, D. Tarassov, A. Jetybayeva, Y. Myngtay, D. Zhalmuratova and D. Nurmukhambetov, Inhibitory effects of polar and non-polar organic substances on activated sludge activity, Desalination and Water Treatment, 91 (2017) 185-191.

[28] V.J. Inglezakis, S. Malamis, A. Omirkhan, J. Nauruzbayeva, Z. Makhtayeva, T. Seidakhmetov and A. Kudarova, Investigating the inhibitory effect of cyanide, phenol and 4-nitrophenol in the activated sludge process employed for the treatment of petroleum wastewater, Journal of Environmental Management, 203 (2017) 825-830. 
This is a peer-reviewed, accepted author manuscript of the following article: Doskaliyev, D., Poulopoulos, S. G., Yeshmuratov, A., Aldyngurova, F., Zorpas, A. A., \& Inglezakis, V. J. (2018). Effects of 2-chlorophenol and 2,4,6-trichlorophenol on an activated sludge sequencing batch reactor. Desalination and Water Treatment, 133, 283-291. https://doi.org/10.5004/dwt.2018.23065

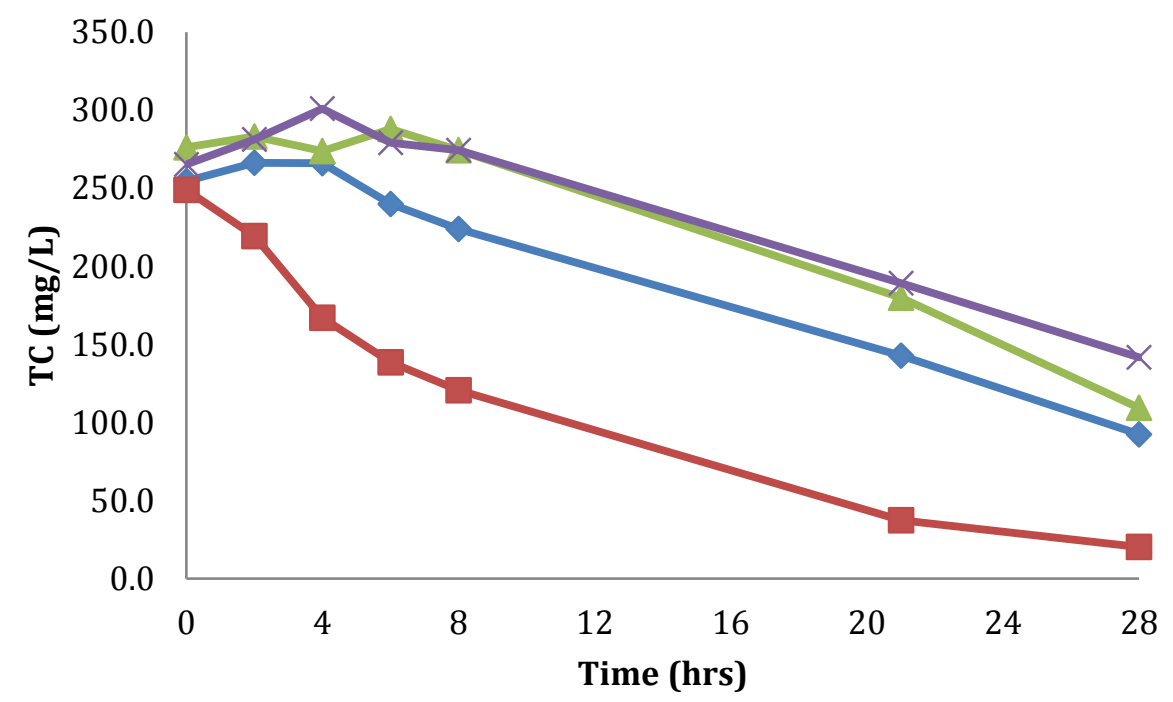

$\sim$ Internal and external aeration; without sludge

-Internal and external aeration; with sludge

- Maximum internal aeration; without sludge

* Half-maximum internal aeration; without sludge

Figure 1. TC removal dynamics.

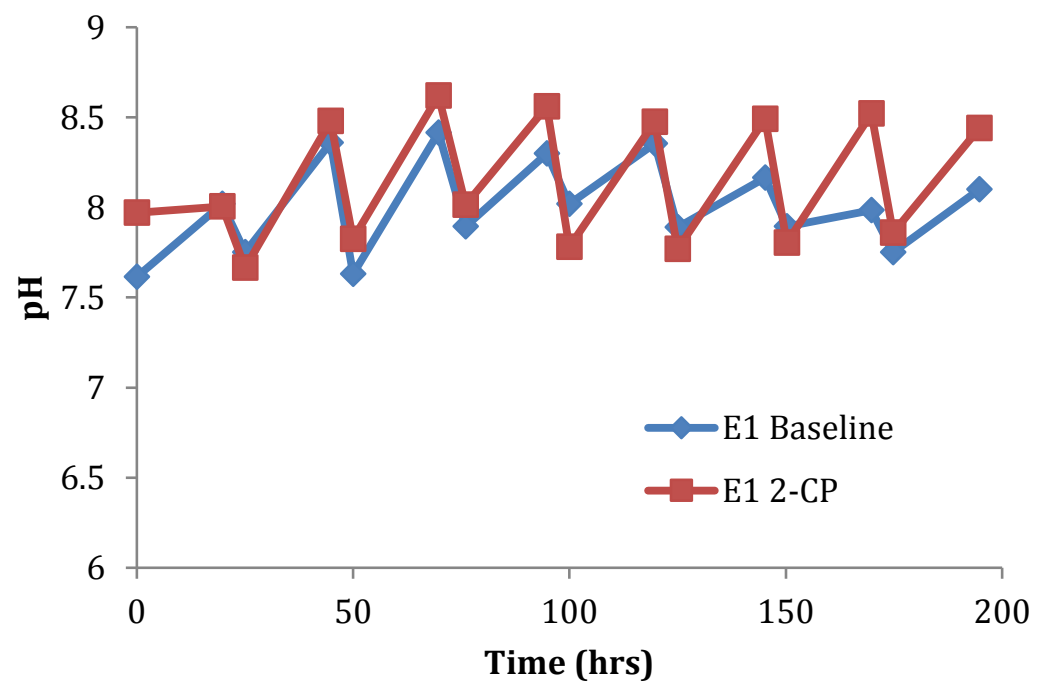

Figure 2. pH evolution (E1). 
This is a peer-reviewed, accepted author manuscript of the following article: Doskaliyev, D., Poulopoulos, S. G., Yeshmuratov, A., Aldyngurova, F., Zorpas, A. A., \& Inglezakis, V. J. (2018). Effects of 2-chlorophenol and 2,4,6-trichlorophenol on an activated sludge sequencing batch reactor. Desalination and Water Treatment, 133, 283-291. https://doi.org/10.5004/dwt.2018.23065

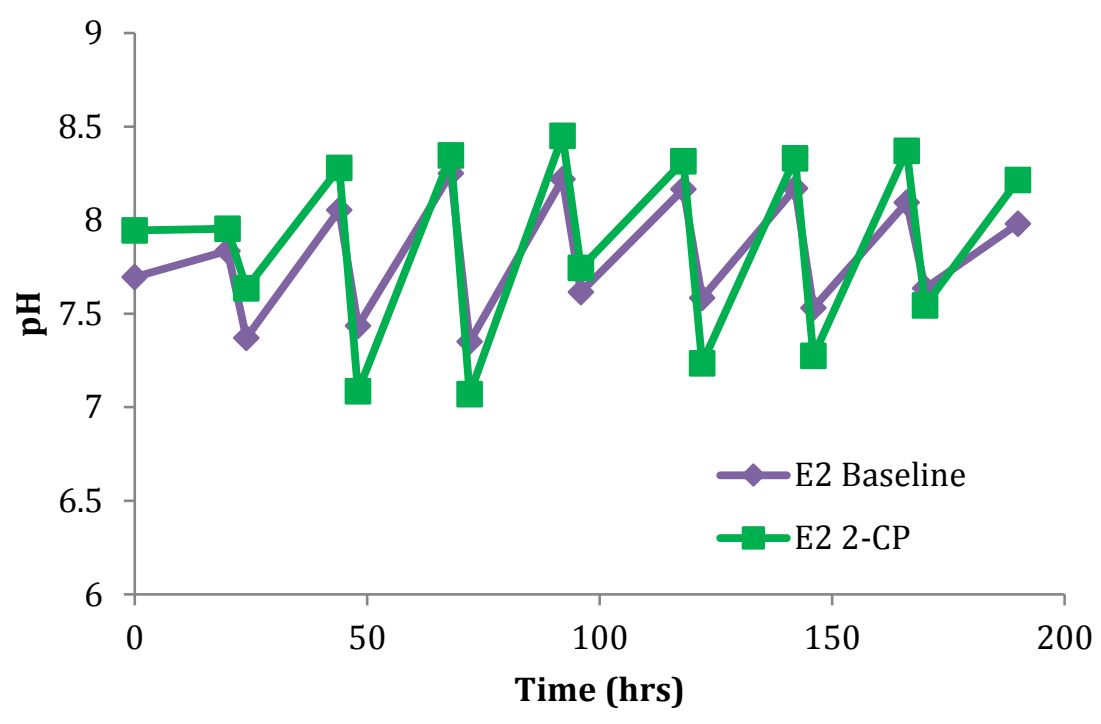

Figure 3. $\mathrm{pH}$ evolution (E2).

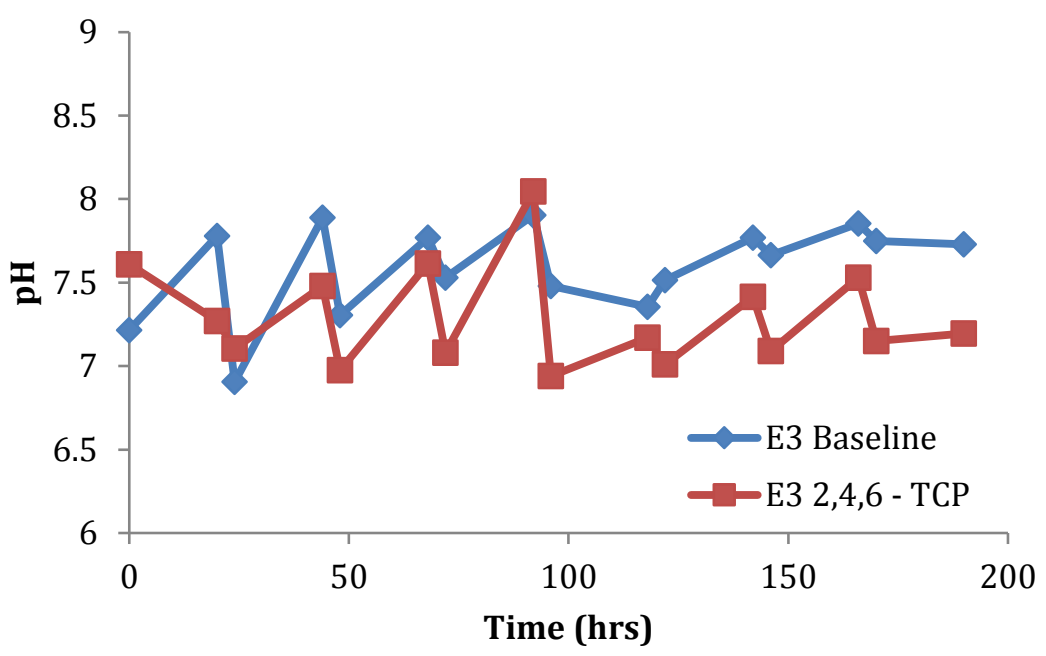

Figure 4. $\mathrm{pH}$ evolution (E3). 
This is a peer-reviewed, accepted author manuscript of the following article: Doskaliyev, D., Poulopoulos, S. G., Yeshmuratov, A., Aldyngurova, F., Zorpas, A. A., \& Inglezakis, V. J. (2018). Effects of 2-chlorophenol and 2,4,6-trichlorophenol on an activated sludge sequencing batch reactor. Desalination and Water Treatment, 133, 283-291. https://doi.org/10.5004/dwt.2018.23065

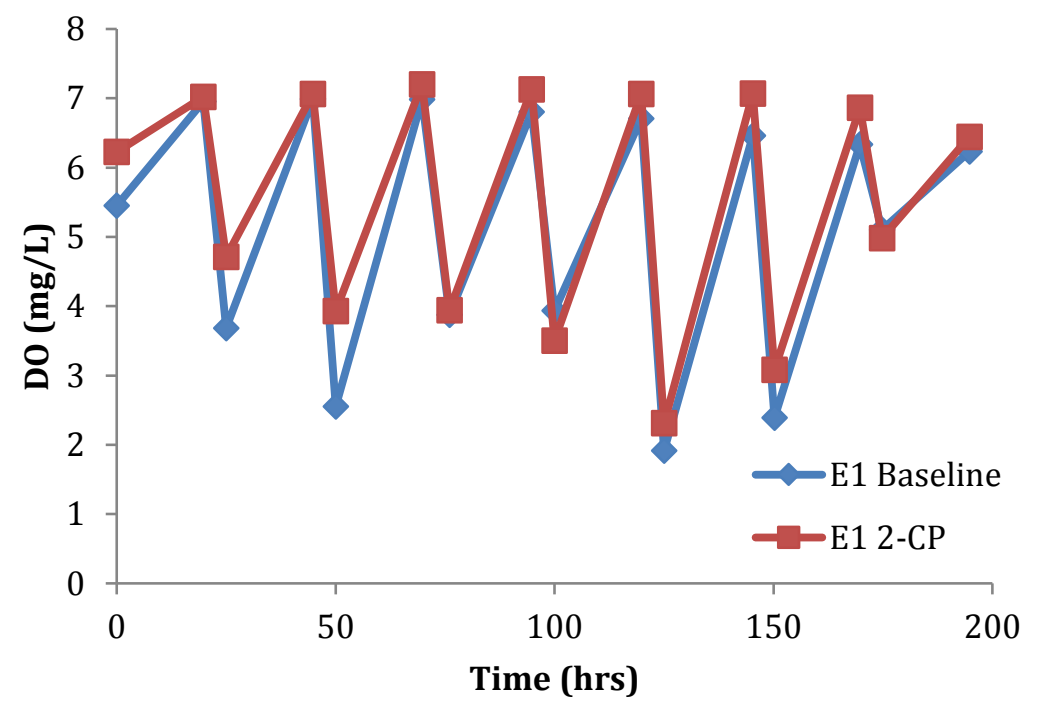

Figure 5. DO evolution (E1).

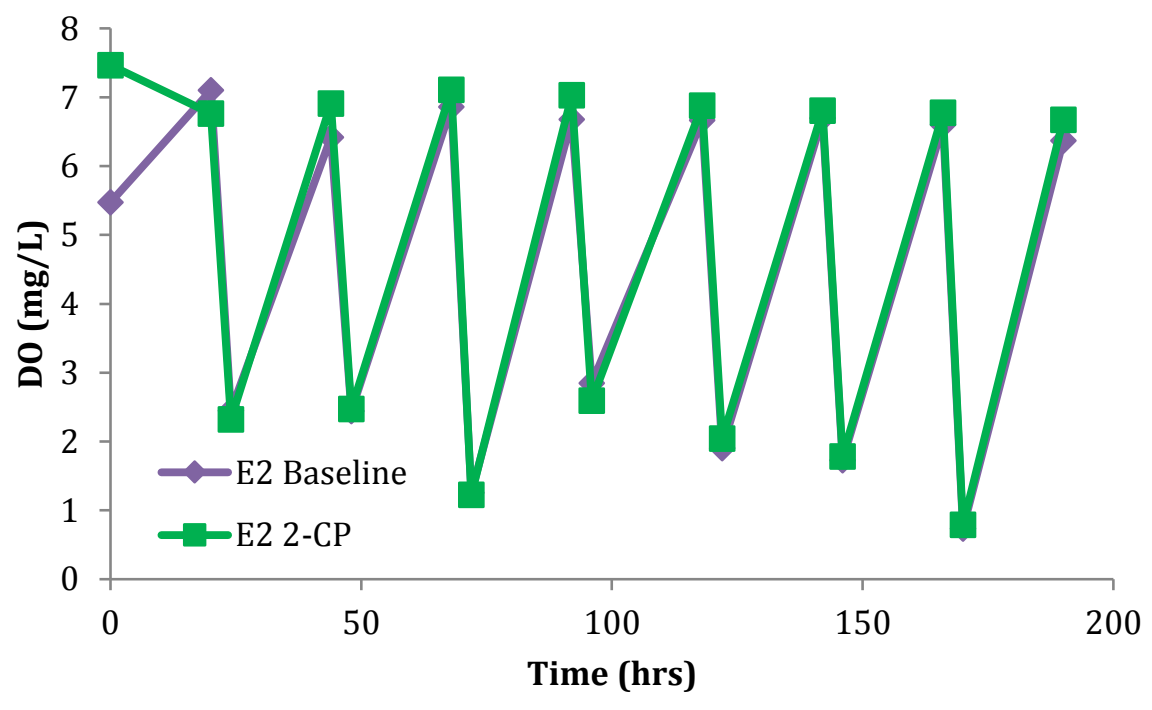

Figure 6. DO evolution (E2). 
This is a peer-reviewed, accepted author manuscript of the following article: Doskaliyev, D., Poulopoulos, S. G., Yeshmuratov, A., Aldyngurova, F., Zorpas, A. A., \& Inglezakis, V. J. (2018). Effects of 2-chlorophenol and 2,4,6-trichlorophenol on an activated sludge sequencing batch reactor. Desalination and Water Treatment, 133, 283-291. https://doi.org/10.5004/dwt.2018.23065

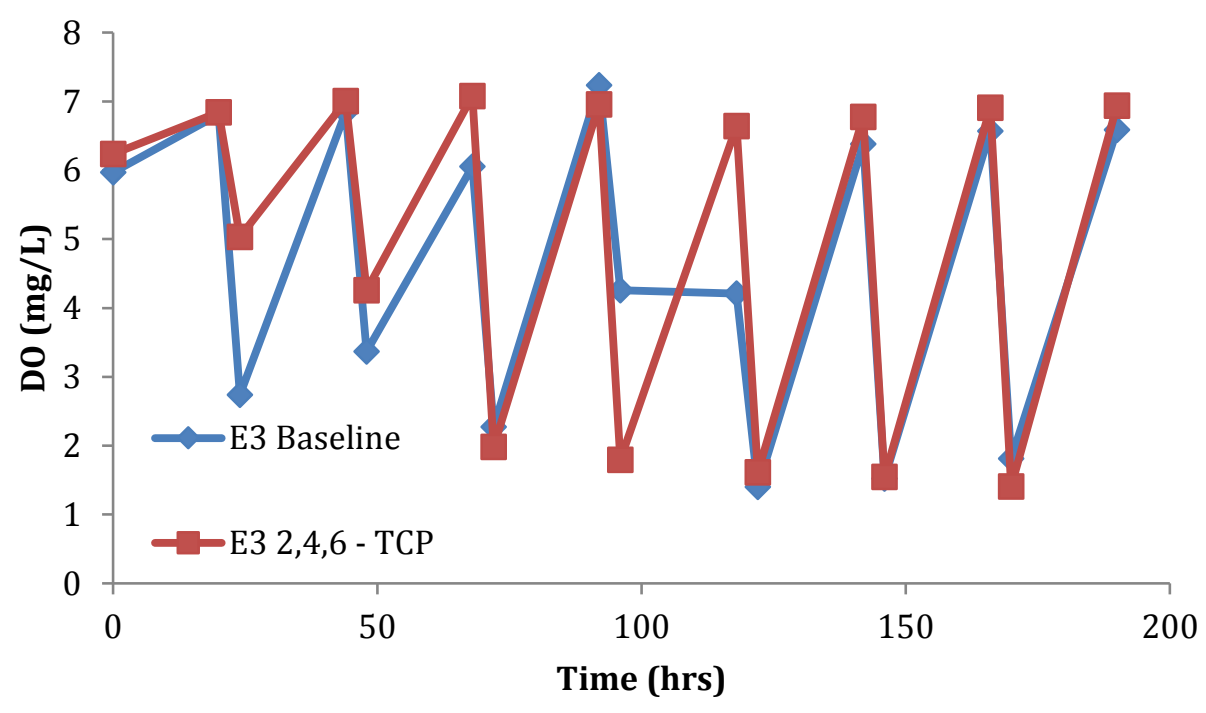

Figure 7. DO data for (E3).

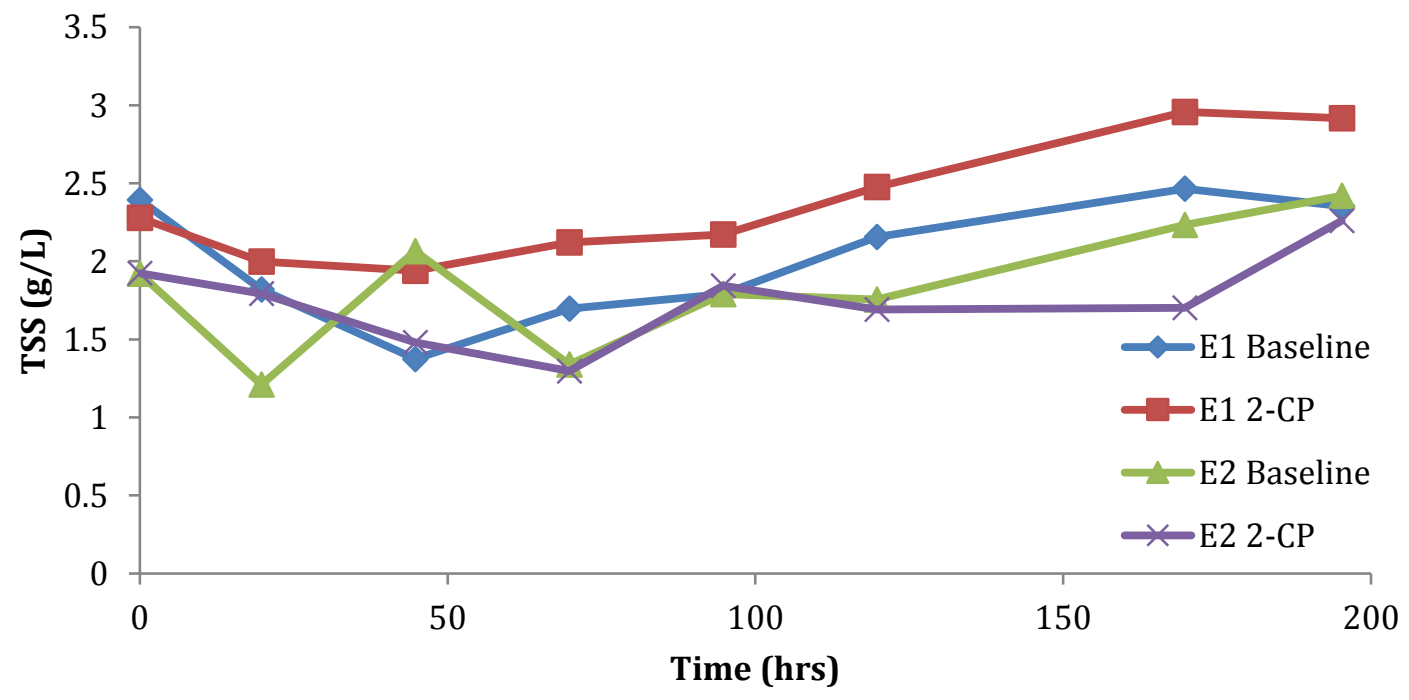

Figure 8. TSS evolution (E1 and E2). 
This is a peer-reviewed, accepted author manuscript of the following article: Doskaliyev, D., Poulopoulos, S. G., Yeshmuratov, A., Aldyngurova, F., Zorpas, A. A., \& Inglezakis, V. J. (2018). Effects of 2-chlorophenol and 2,4,6-trichlorophenol on an activated sludge sequencing batch reactor. Desalination and Water Treatment, 133, 283-291. https://doi.org/10.5004/dwt.2018.23065

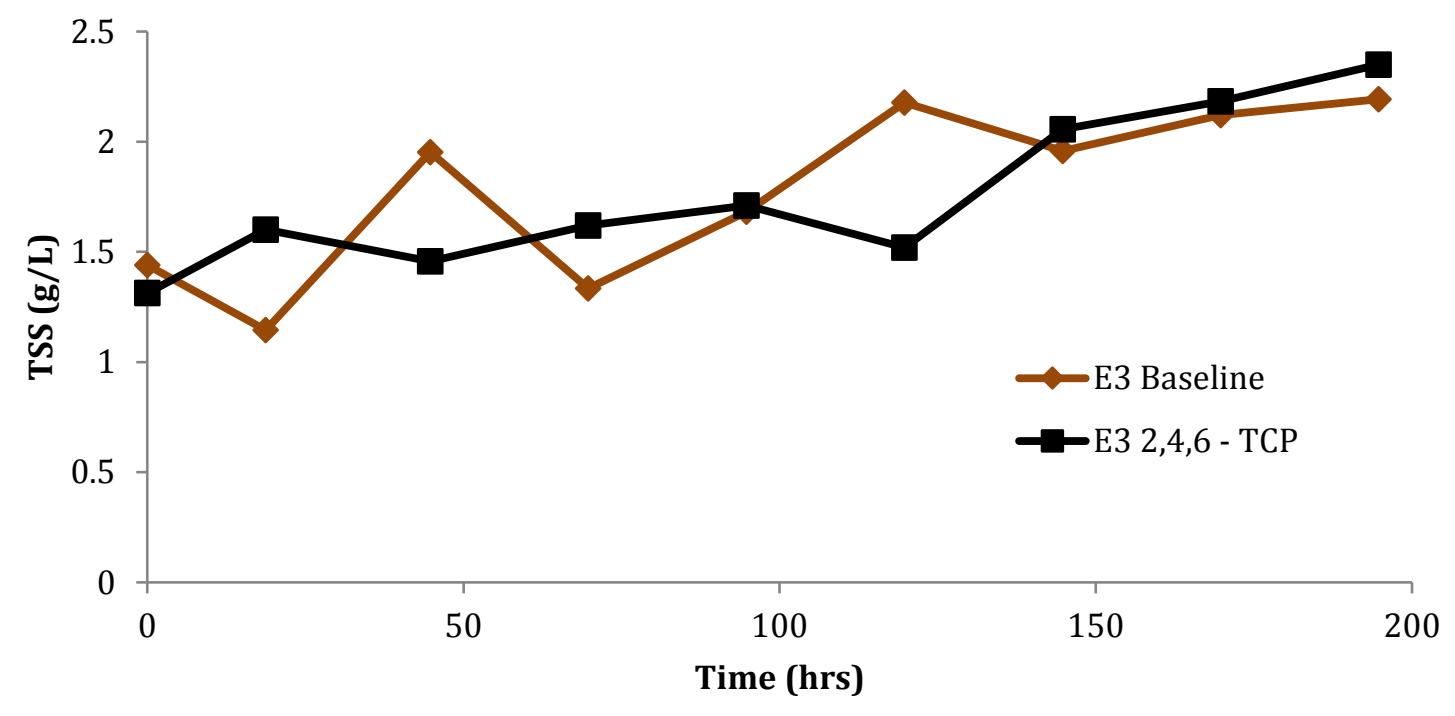

Figure 9. TSS evolution (E3).

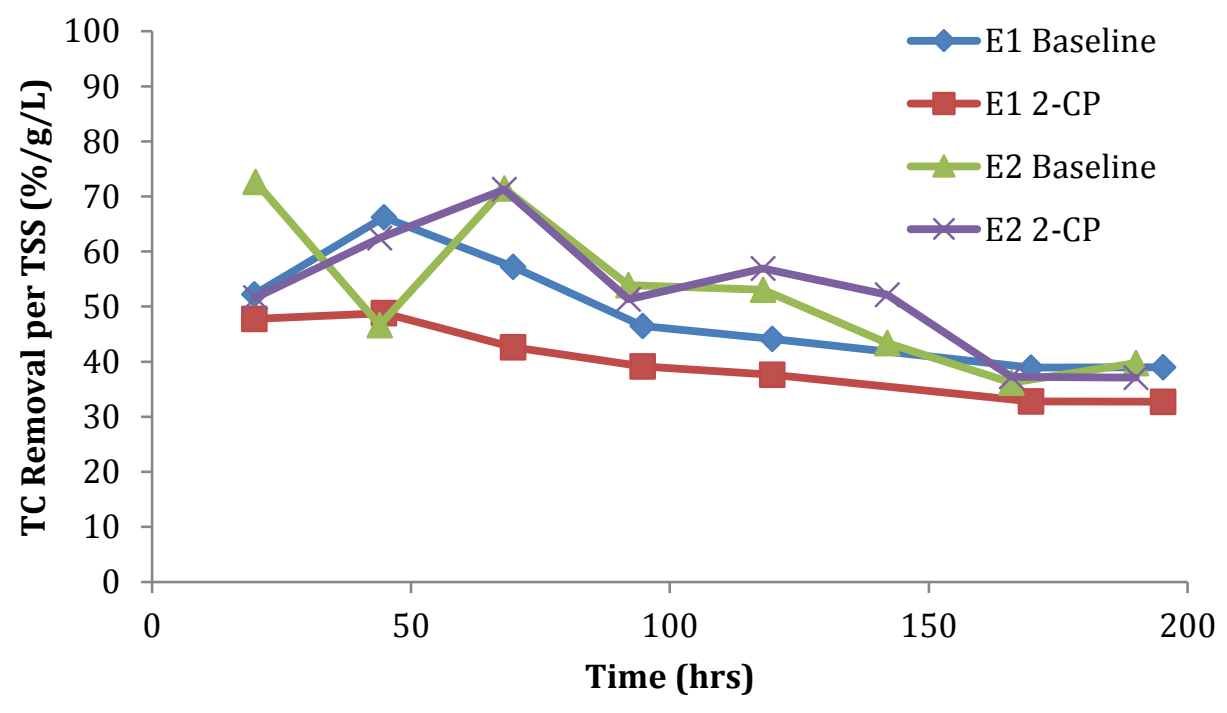

Figure 10. TC removal per TSS (E1 and E2). 
This is a peer-reviewed, accepted author manuscript of the following article: Doskaliyev, D., Poulopoulos, S. G., Yeshmuratov, A., Aldyngurova, F., Zorpas, A. A., \& Inglezakis, V. J. (2018). Effects of 2-chlorophenol and 2,4,6-trichlorophenol on an activated sludge sequencing batch reactor. Desalination and Water Treatment, 133, 283-291. https://doi.org/10.5004/dwt.2018.23065

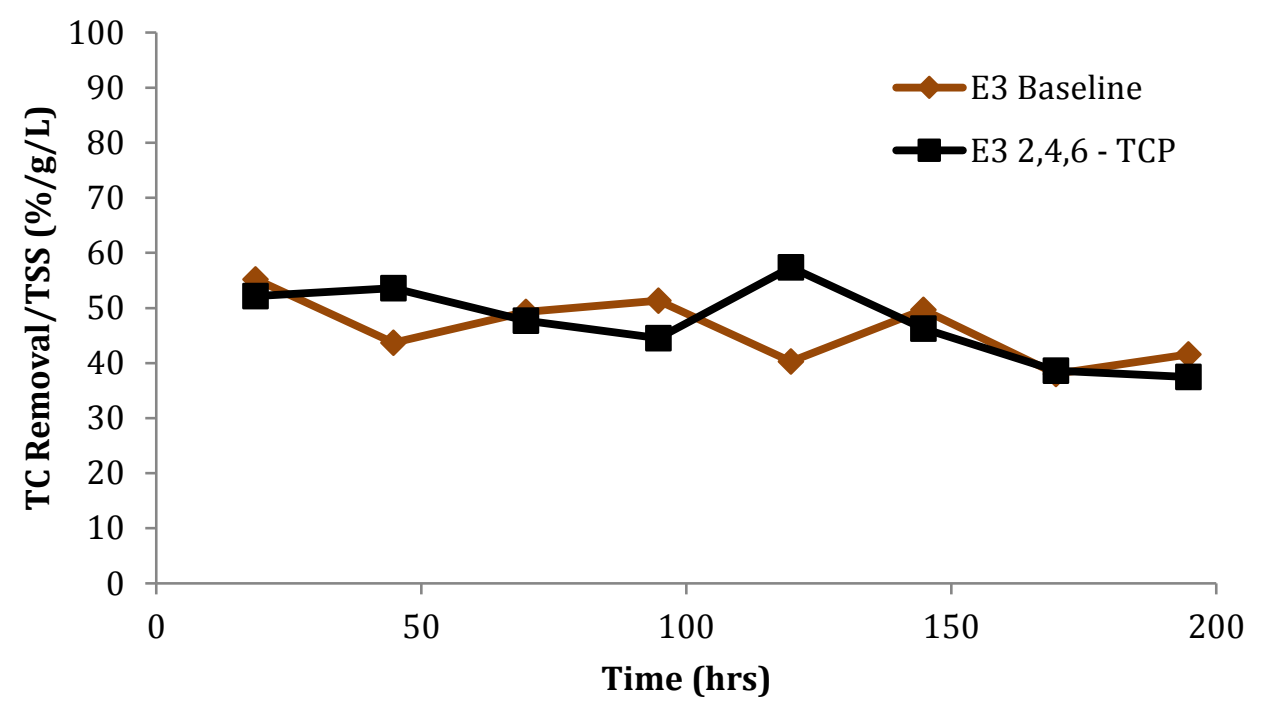

Figure 11. TC removal per TSS data (E3).

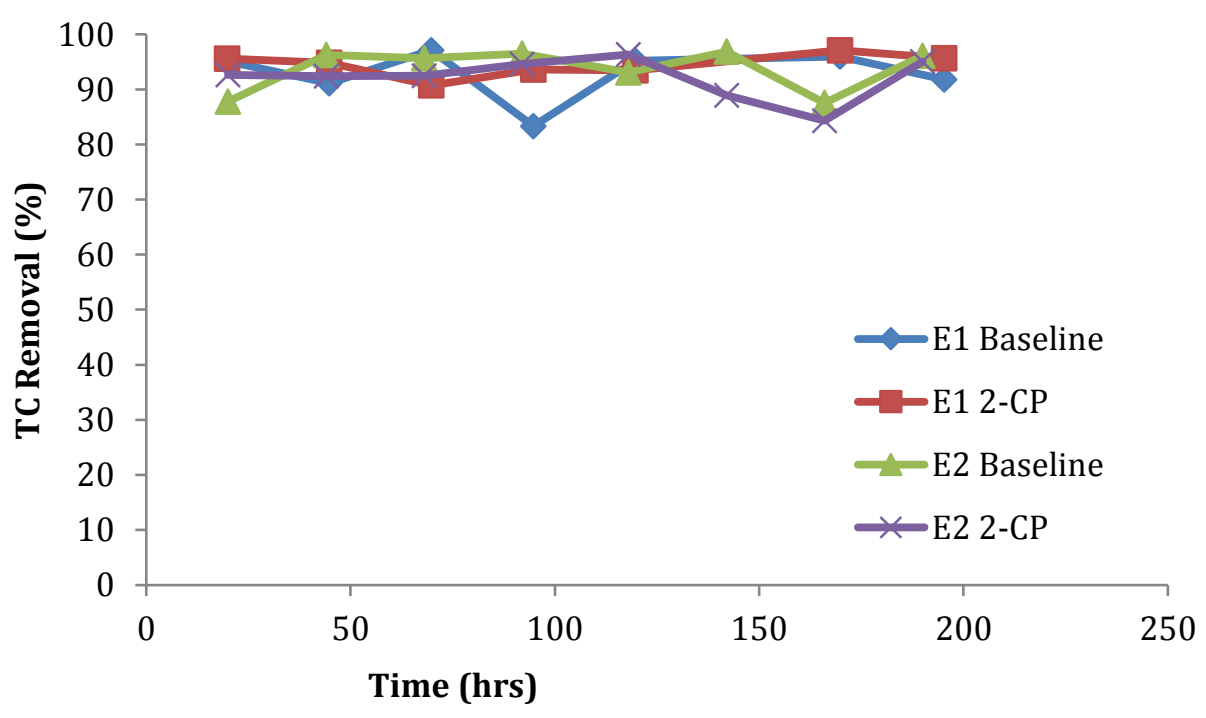

Figure 12. TC removal (E1 and E2). 
This is a peer-reviewed, accepted author manuscript of the following article: Doskaliyev, D., Poulopoulos, S. G., Yeshmuratov, A., Aldyngurova, F., Zorpas, A. A., \& Inglezakis, V. J. (2018). Effects of 2-chlorophenol and 2,4,6-trichlorophenol on an activated sludge sequencing batch reactor. Desalination and Water Treatment, 133, 283-291. https://doi.org/10.5004/dwt.2018.23065

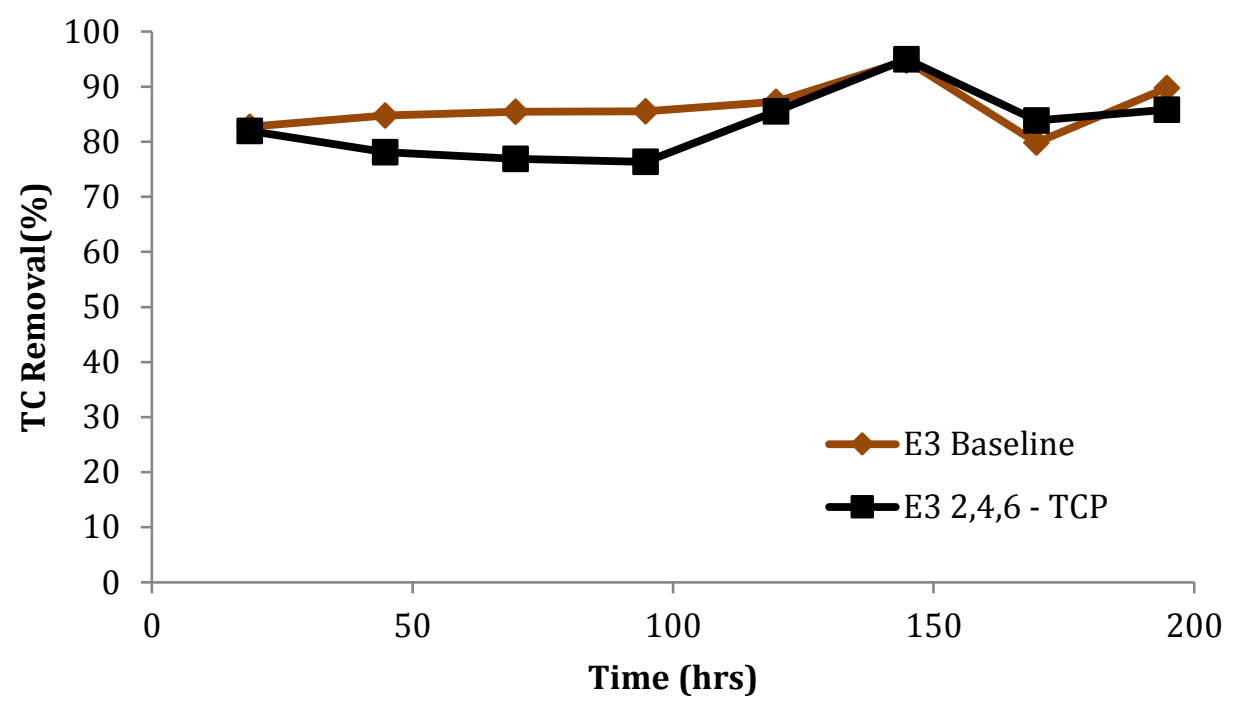

Figure 13. TC removal (E3).

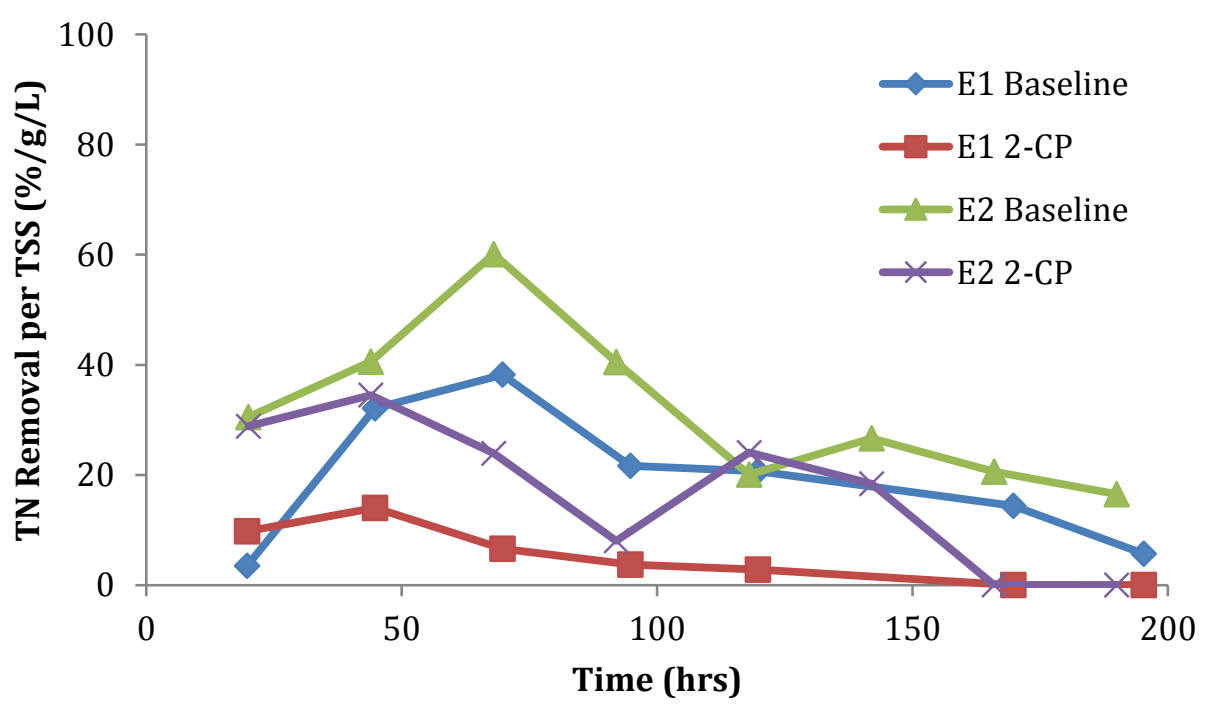

Figure 14. TN removal per TSS (E1 and E2). 
This is a peer-reviewed, accepted author manuscript of the following article: Doskaliyev, D., Poulopoulos, S. G., Yeshmuratov, A., Aldyngurova, F., Zorpas, A. A., \& Inglezakis, V. J. (2018). Effects of 2-chlorophenol and 2,4,6-trichlorophenol on an activated sludge sequencing batch reactor. Desalination and Water Treatment, 133, 283-291. https://doi.org/10.5004/dwt.2018.23065

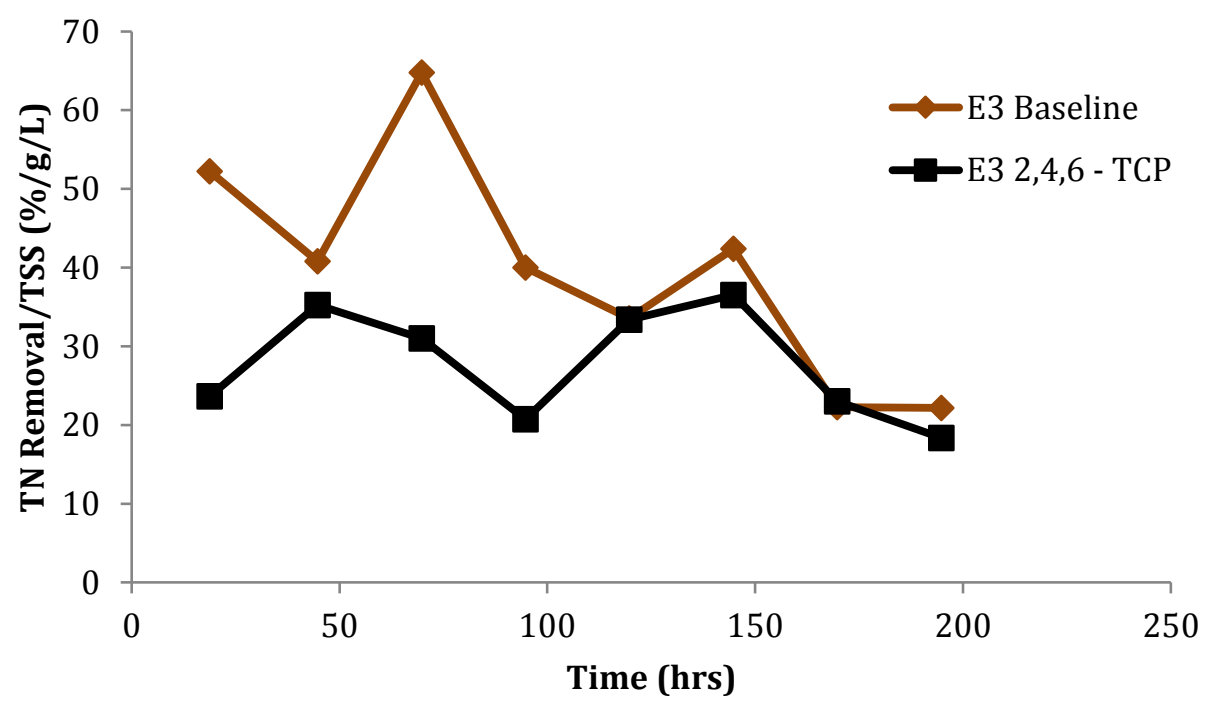

Figure 15. TN removal per TSS (E3).

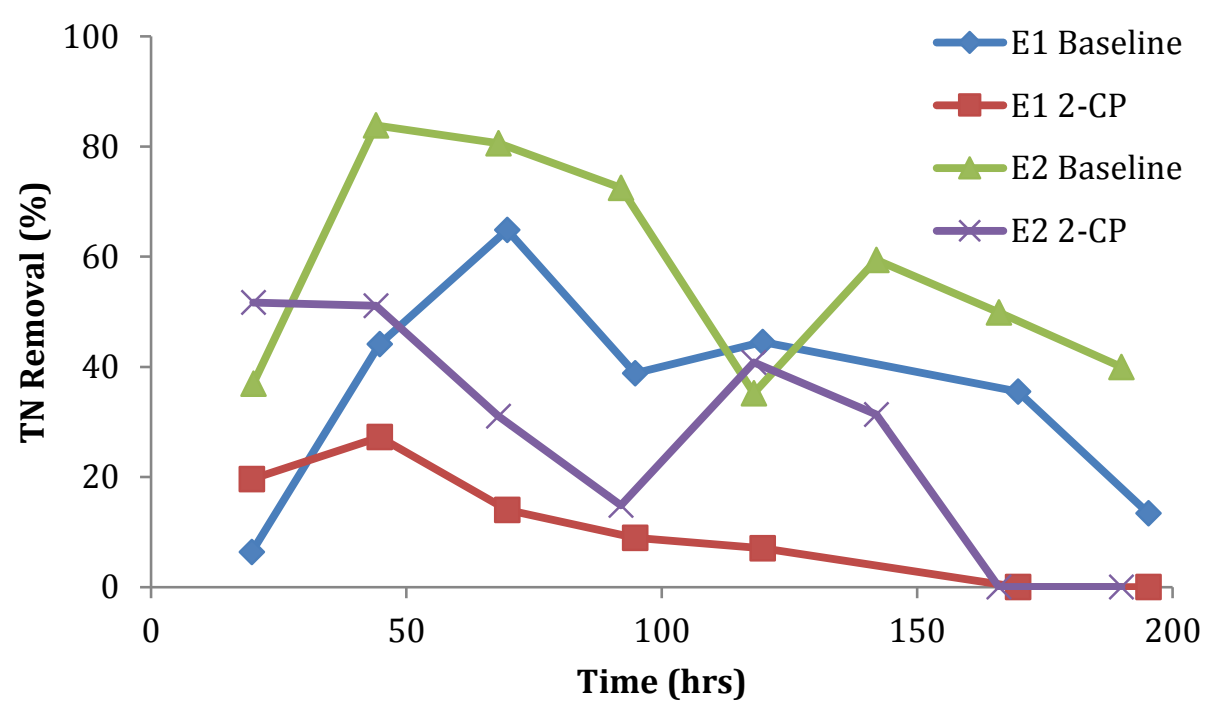

removal (E1 and E2).

Figure 16. TN 
This is a peer-reviewed, accepted author manuscript of the following article: Doskaliyev, D., Poulopoulos, S. G., Yeshmuratov, A., Aldyngurova, F., Zorpas, A. A., \& Inglezakis, V. J. (2018). Effects of 2-chlorophenol and 2,4,6-trichlorophenol on an activated sludge sequencing batch reactor. Desalination and Water Treatment, 133, 283-291. https://doi.org/10.5004/dwt.2018.23065

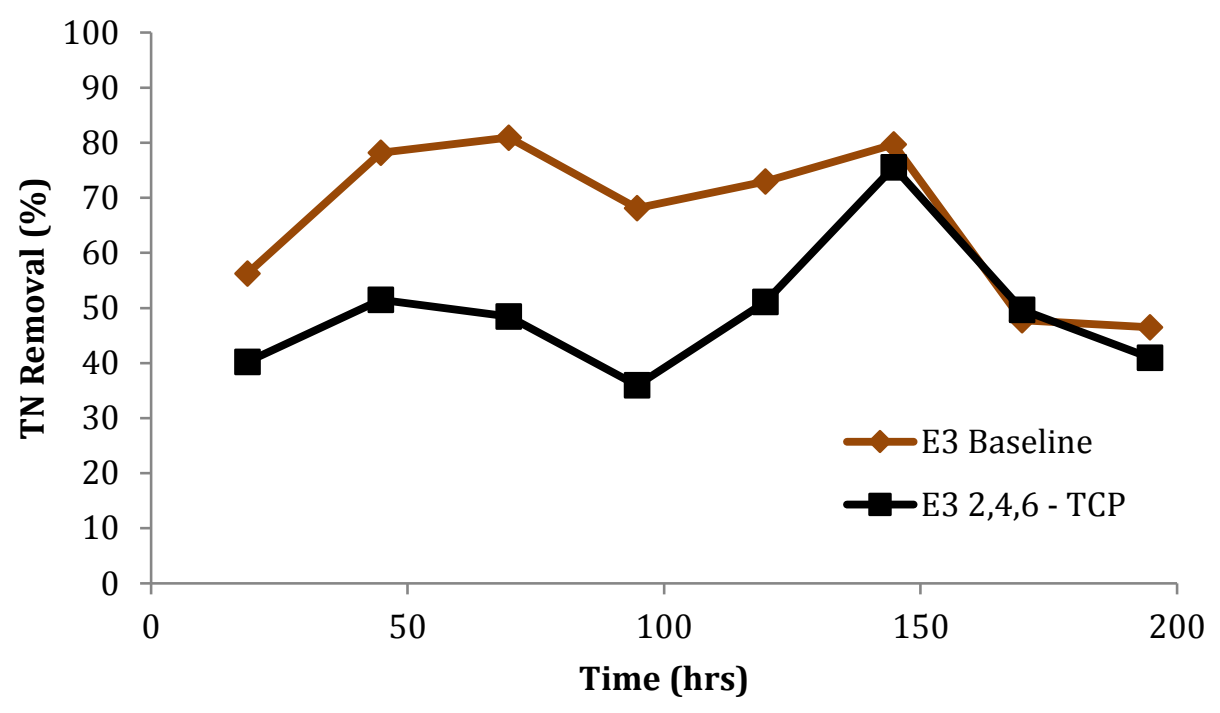

Figure 17. TN removal (E3).

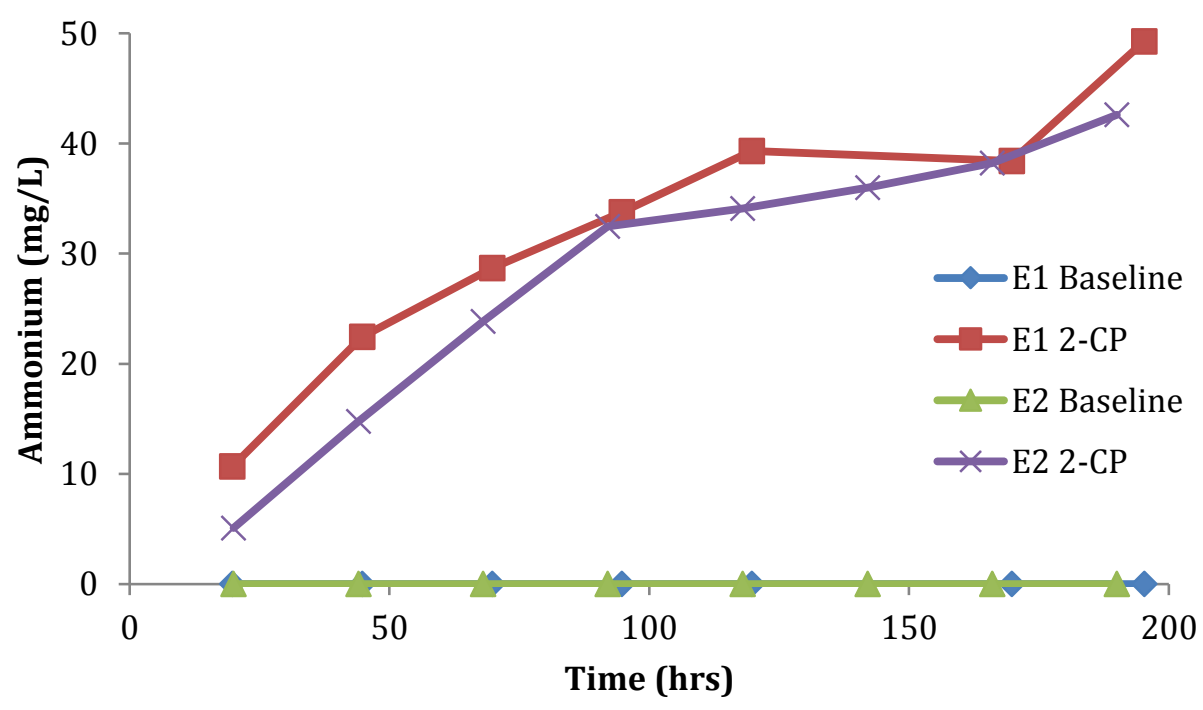

Figure 18. Effluent ammonium concentration (E1 and E2). 
This is a peer-reviewed, accepted author manuscript of the following article: Doskaliyev, D., Poulopoulos, S. G., Yeshmuratov, A., Aldyngurova, F., Zorpas, A. A., \& Inglezakis, V. J. (2018). Effects of 2-chlorophenol and 2,4,6-trichlorophenol on an activated sludge sequencing batch reactor. Desalination and Water Treatment, 133, 283-291. https://doi.org/10.5004/dwt.2018.23065

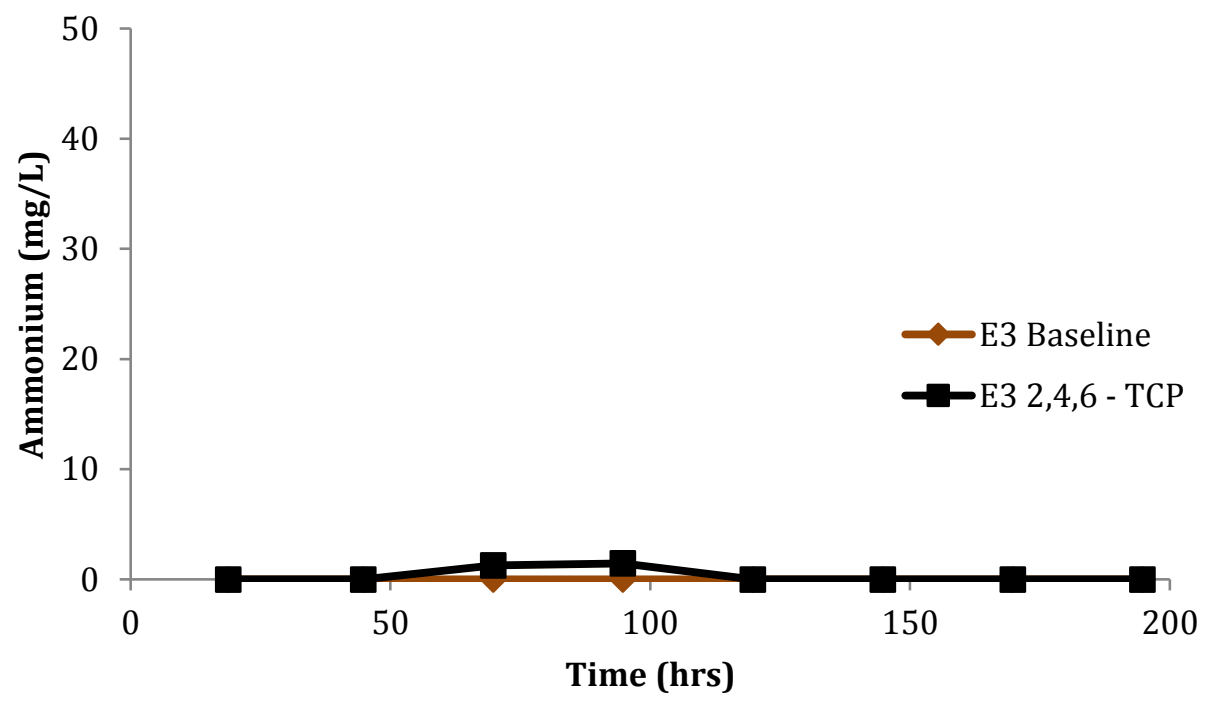

Figure 19. Effluent ammonium concentration (E3).

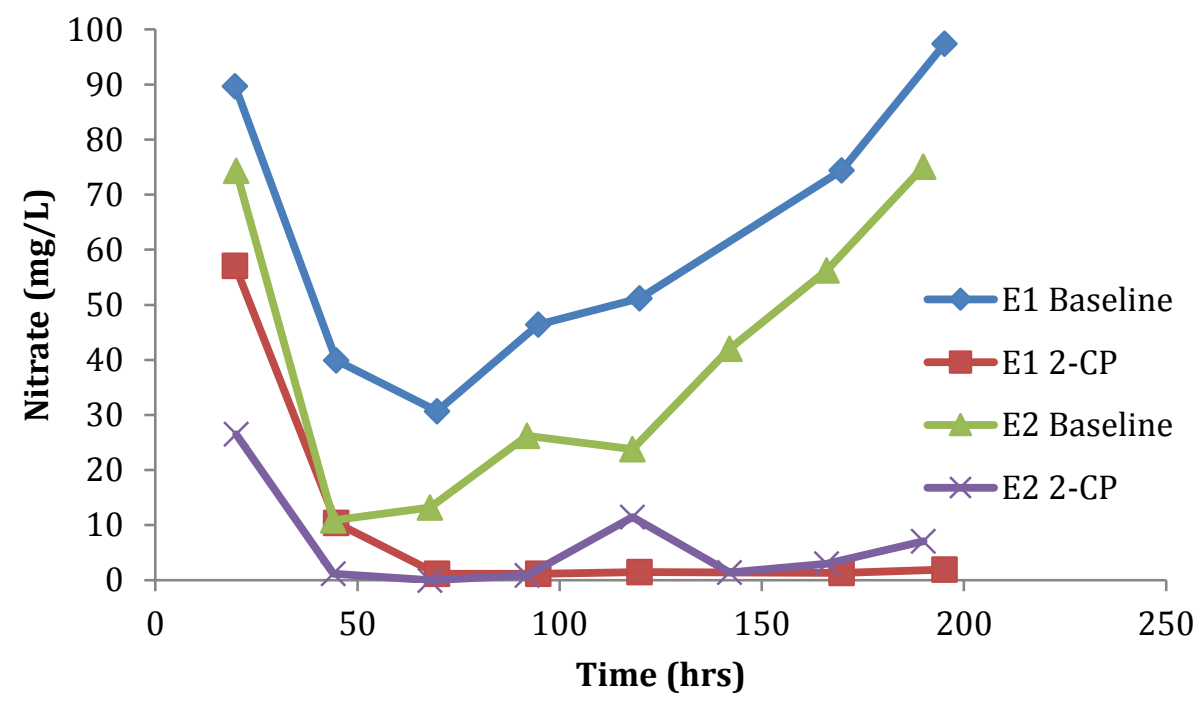

production (E1 and E2).

Figure 20. Nitrates 
This is a peer-reviewed, accepted author manuscript of the following article: Doskaliyev, D., Poulopoulos, S. G., Yeshmuratov, A., Aldyngurova, F., Zorpas, A. A., \& Inglezakis, V. J. (2018). Effects of 2-chlorophenol and 2,4,6-trichlorophenol on an activated sludge sequencing batch reactor. Desalination and Water Treatment, 133, 283-291. https://doi.org/10.5004/dwt.2018.23065

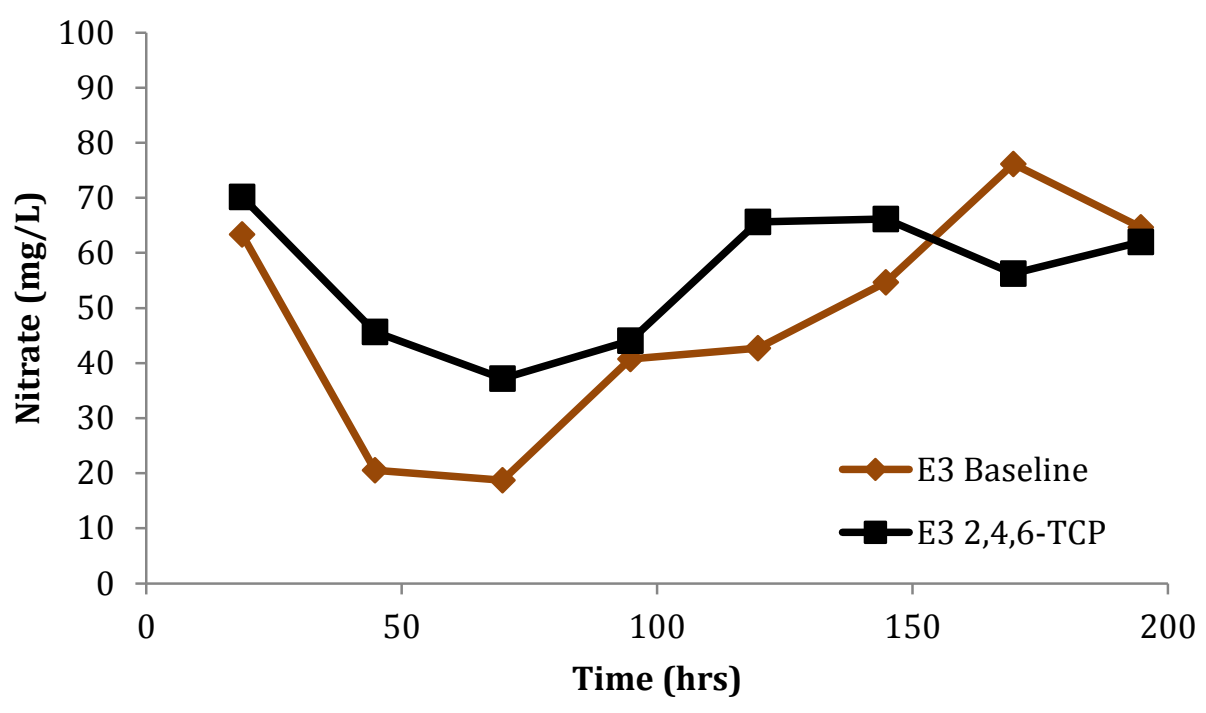

Figure 21. Nitrates production (E3).

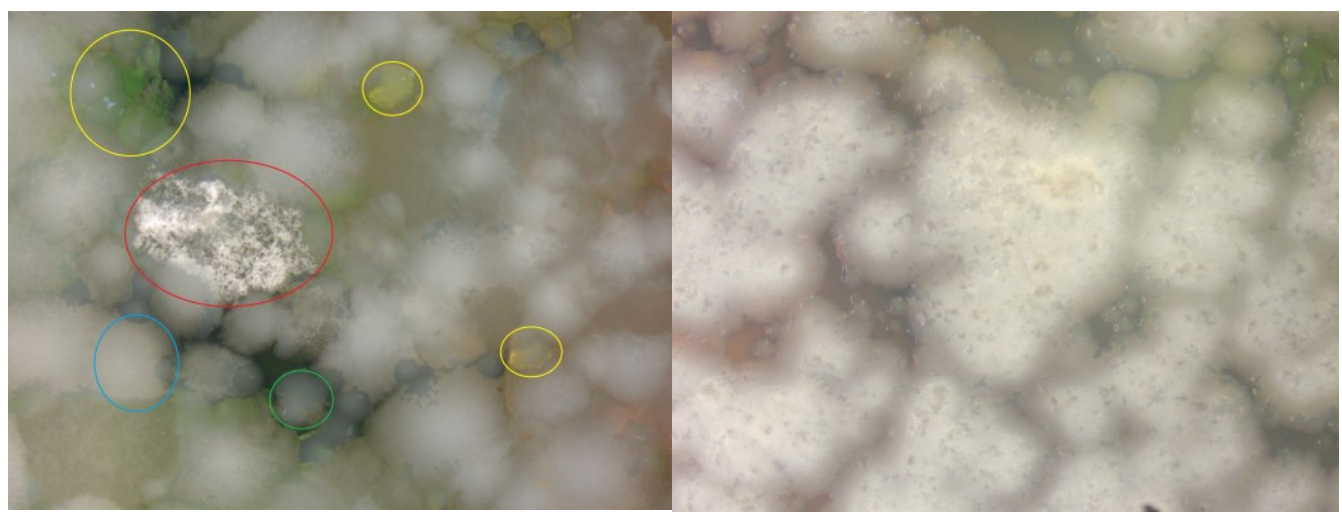

Figure 22. Microbiological analysis feed without (left) and with 2-CP (right). 
This is a peer-reviewed, accepted author manuscript of the following article: Doskaliyev, D., Poulopoulos, S. G., Yeshmuratov, A., Aldyngurova, F., Zorpas, A. A., \& Inglezakis, V. J. (2018). Effects of 2-chlorophenol and 2,4,6-trichlorophenol on an activated sludge sequencing batch reactor. Desalination and Water Treatment, 133, 283-291. https://doi.org/10.5004/dwt.2018.23065

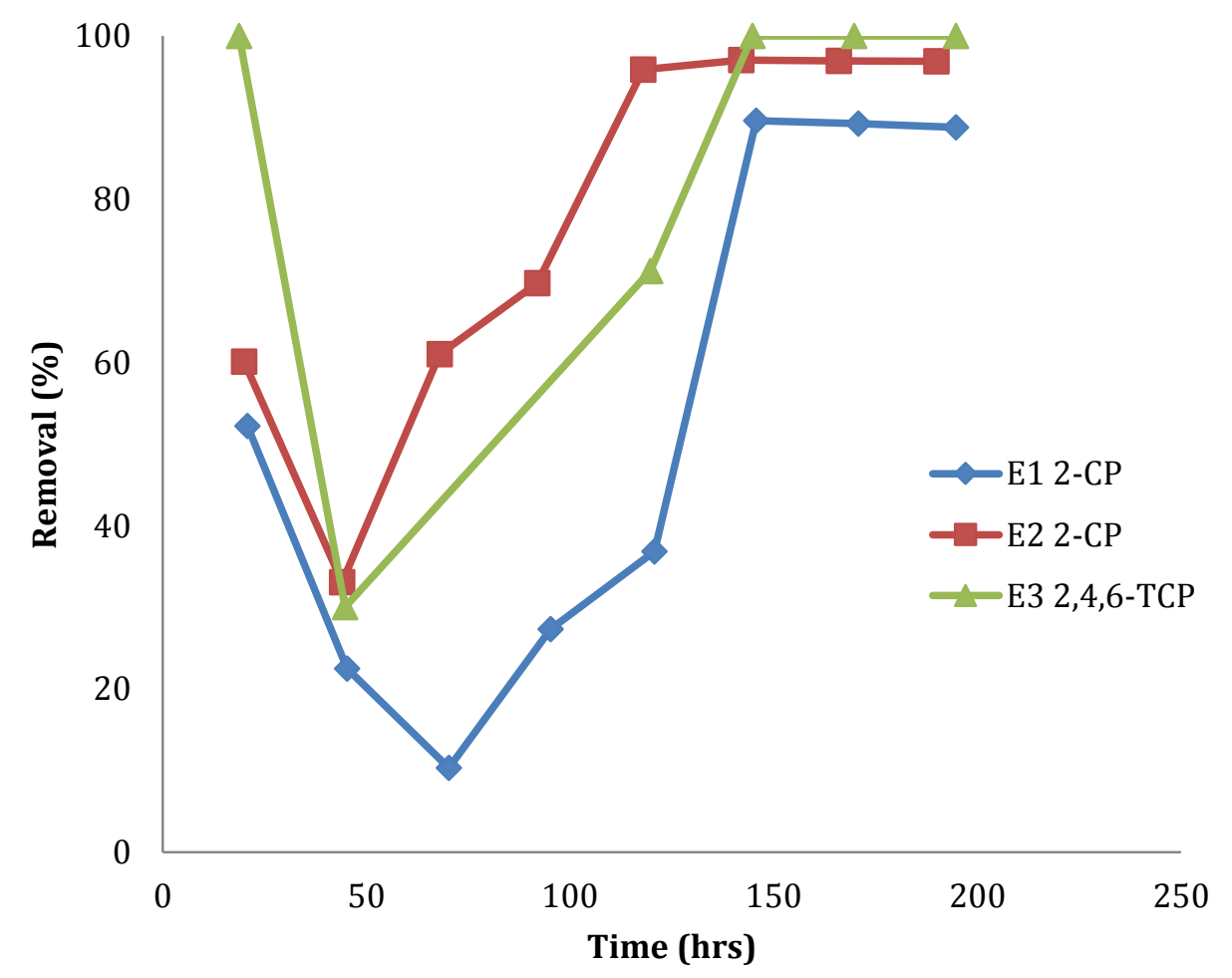

Figure 23. 2-CP (E1 and E2) and 2,4,6-TCP removal (E3). 
Table 1. Summary of studies on phenols effects on activated sludge SBRs performance.

\begin{tabular}{|c|c|c|c|c|c|}
\hline Phenol & $\begin{array}{c}\text { Concentrat } \\
\text { ion } \\
(\mathrm{mg} / \mathrm{L})\end{array}$ & SBR Cycles & $\begin{array}{l}\text { Phenols } \\
\text { degradat } \\
\text { ion }\end{array}$ & $\begin{array}{c}\text { COD/ } \\
\text { Ammonium } \\
\text { removal }\end{array}$ & Reference \\
\hline $\begin{array}{c}2,4- \\
\text { Dichlorophen } \\
\text { ol }\end{array}$ & $\begin{array}{c}5(\text { Stage } 2) \\
15(\text { Stage } 3) \\
30(\text { Stage } 4)\end{array}$ & $\begin{array}{l}\text { Total cycle length: } 24 \\
\text { hrs. } \\
\text { - Fill: } 2 . \\
\text { - React: } 12 \text { (9: } \\
\text { nitrification, } \\
\text { 3:denitrification) } \\
\text { - Settle: } 1 \mathrm{hr} \\
\text { - Draw: } 1 \mathrm{hr} \\
\text { - Idle: } 8 \mathrm{hr}\end{array}$ & $\begin{array}{c}100 \% \\
(\text { Stage } 2) \\
91 \% \\
(\text { Stage } 3) \\
41 \% \\
(\text { Stage } 4)\end{array}$ & $\begin{array}{c}-/ 100 \% \\
(\text { Stage } 2) \\
-/ 100 \% \\
(\text { Stage } 3) \\
-/ 25 \% \\
\text { (Stage 4) }\end{array}$ & [8] \\
\hline $\begin{array}{c}\text { 4- } \\
\text { chlorophenol }\end{array}$ & 200 & Not available & $34 \%$ & $76 \% / 72 \%$ & [19] \\
\hline $\begin{array}{c}\text { 4- } \\
\text { chlorophenol }\end{array}$ & $\begin{array}{l}2 \text { (Phase } 1- \\
2 \text { ) } \\
5 \text { (Phase } 3- \\
4 \text { ) }\end{array}$ & $\begin{array}{l}\text { Phase 1. Total cycle } \\
\text { length: } 24 \text { hrs. } \\
\text { - Fill: } 1 \text { hrs } \\
\text { - React: } 22 \\
\text { - Settle, Draw: } 1 \\
\text { Phase } 2 \text {. Total cycle } \\
\text { length: } 12 \text { hrs } \\
\text { - Fill: } 1 \\
\text { - React: } 10 \\
\text {-Settle, Draw: } 1 \\
\text { Phase } 3-4 . \\
\text { Total cycle } \\
\text { length: } 6 \text { hrs } \\
\text {-Fill: } 1 \\
\text {-React:4 } \\
\text {-Settle, Draw: } 1\end{array}$ & $\begin{array}{c}100 \% \\
\text { (Phase 1- } \\
2) \\
100 \% \\
\text { (Phase 3- } \\
4)\end{array}$ & $\begin{array}{c}<90 \% / \text { nitrifi } \\
\text { cation } \\
\text { inhibition } \\
\text { (Phase 1) } \\
<90 \% / \text { very } \\
\text { high } \\
\text { ammonium } \\
\text { removal } \\
\text { (Phase } 2-4)\end{array}$ & {$[20]$} \\
\hline
\end{tabular}


This is a peer-reviewed, accepted author manuscript of the following article: Doskaliyev, D., Poulopoulos, S. G., Yeshmuratov, A., Aldyngurova, F., Zorpas, A. A., \& Inglezakis, V. J. (2018). Effects of 2-chlorophenol and 2,4,6-trichlorophenol on an activated sludge sequencing batch reactor. Desalination and Water Treatment, 133, 283-291. https://doi.org/10.5004/dwt.2018.23065

\begin{tabular}{|c|c|c|c|c|c|}
\hline Phenol & $\begin{array}{c}\text { 1) } 0-400 \\
\text { 2) } 400-600\end{array}$ & $\begin{array}{l}\text { - Fill: N/A } \\
\text { - React: } 1 \mathrm{hr} . \\
\text { (anaerobic), } 3 \mathrm{hr} \text {. (oxic), } \\
1 \mathrm{hr} \text { (anoxic), } 1 \mathrm{hr} \text { (oxic) } \\
\text { - Settle: } 0.75 \mathrm{hr} \\
\text { - Draw: N/A }\end{array}$ & $\begin{array}{l}\text { 1) } 95 \% \\
\text { 2) } 65 \%\end{array}$ & $\begin{array}{c}1) \\
<95 \% /<90 \% \\
\text { 2) } 79 \% / 78 \%\end{array}$ & [21] \\
\hline
\end{tabular}

Table 2. Synthetic wastewater composition

\begin{tabular}{cc}
\hline Component & Concentration $(\mathbf{g} / \mathbf{L})$ \\
\hline Glucose & 0.53 \\
Bacterial Peptone & 0.16 \\
Lab Lemco & 0.31 \\
Ammonium Hydrogen Carbonate & 0.05 \\
Potassium Hydrogen Carbonate & 0.03 \\
Sodium Hydrogen Carbonate & 0.03 \\
$\mathrm{FeCl}_{3}$ & $0.33^{*} 10^{-3}$ \\
$\mathrm{CaCl}_{3}$ & $0.33^{*} 10^{-3}$ \\
$\mathrm{KCl}^{2}$ & $0.06^{*} 10^{-3}$ \\
\hline
\end{tabular}

Table 3. Different experiment modes for air stripping experiment.

\begin{tabular}{c|c|c|c}
\hline Run \# & Description & $\begin{array}{c}\text { Aeration } \\
\text { mode; } \\
\text { magnitude }\end{array}$ & Purpose \\
\hline 1 & $\begin{array}{c}\text { Without sludge; } \\
\text { synthetic wastewater } \\
\text { without }\end{array}$ & $\begin{array}{c}\text { Internal and } \\
\text { external; } \\
\text { maximum }\end{array}$ & $\begin{array}{c}\text { To evaluate the role of aeration in TC } \\
\text { removal }\end{array}$ \\
\hline
\end{tabular}


This is a peer-reviewed, accepted author manuscript of the following article: Doskaliyev, D., Poulopoulos, S. G., Yeshmuratov, A., Aldyngurova, F., Zorpas, A. A., \& Inglezakis, V. J. (2018). Effects of 2-chlorophenol and 2,4,6-trichlorophenol on an activated sludge sequencing batch reactor. Desalination and Water Treatment, 133, 283-291. https://doi.org/10.5004/dwt.2018.23065

\begin{tabular}{|c|c|c|c|}
\hline & chlorophenol & (both) & \\
\hline 2 & $\begin{array}{c}\text { With sludge; } \\
\text { synthetic wastewater } \\
\text { without } \\
\text { chlorophenol }\end{array}$ & $\begin{array}{l}\text { Internal and } \\
\text { external; } \\
\text { maximum } \\
\text { (both) }\end{array}$ & $\begin{array}{l}\text { To evaluate the combined role of } \\
\text { sludge and aerators in TC removal }\end{array}$ \\
\hline 3 & $\begin{array}{c}\text { Without sludge; } \\
\text { synthetic wastewater } \\
\text { with } \\
\text { 2-CP }\end{array}$ & $\begin{array}{l}\text { Internal and } \\
\text { external; } \\
\text { maximum } \\
\text { (both) }\end{array}$ & $\begin{array}{l}\text { To evaluate the role of sole aeration in } \\
\text { TC and } 2-\mathrm{CP} \text { removal }\end{array}$ \\
\hline 4 & $\begin{array}{c}\text { Without sludge; } \\
\text { synthetic wastewater } \\
\text { with } \\
\text { 2,4,6-TCP }\end{array}$ & $\begin{array}{l}\text { Internal and } \\
\text { external; } \\
\text { maximum } \\
\text { (both) }\end{array}$ & $\begin{array}{l}\text { To evaluate the role of sole aeration in } \\
\text { TC and 2,4,6-TCP removal }\end{array}$ \\
\hline 5 & $\begin{array}{c}\text { Without sludge; } \\
\text { synthetic wastewater } \\
\text { without } \\
\text { chlorophenol }\end{array}$ & $\begin{array}{l}\text { Internal; } \\
\text { maximum }\end{array}$ & $\begin{array}{l}\text { To evaluate the role of reactor aerator } \\
\text { in TC removal }\end{array}$ \\
\hline 6 & $\begin{array}{c}\text { Without sludge; } \\
\text { synthetic wastewater } \\
\text { without } \\
\text { chlorophenol }\end{array}$ & $\begin{array}{l}\text { Internal; } \\
\text { half }\end{array}$ & $\begin{array}{l}\text { To evaluate the role of reactor aerator } \\
\text { in TC removal }\end{array}$ \\
\hline
\end{tabular}

